\title{
Vernacular Legalism in the Ottoman Empire: Confession, Law, and Popular Politics in the Debate over the "Religion of Abraham (millet-i Ibrāhìm)"
}

\author{
Nir Shafir \\ Assistant Professor of History, University of California, San Diego, United \\ States \\ nshafir@ucsd.edu
}

\begin{abstract}
In the seventeenth century, Ottoman jurists repeatedly tried to stop Muslims from stating that they "belonged to the religion of Abraham." A century earlier, however, the expression had been a core part of the new confessional identity of the empire's Muslims. This article explores how the phrase changed from an attestation of faith to a sign of heresy through a study of a short pamphlet by Minkārīzāde Yahyā Efendi. Minkārizzāde argued that the use of the phrase is not permissible and addressed his arguments not to learned scholars, but to the semi-educated. I argue that Minkārīzāde's pamphlet provides a glimpse into "vernacular legalism" in action in the Ottoman Empire, that is, how semi-educated audiences received and understood legal debates and subsequently turned law into a space of popular politics.
\end{abstract}

\section{Keywords}

millet-i Ibrāhìm - religion - confessionalization - popular law - Abrahamic religions Ottoman - vernacular - Minkāāizāde - early modern

Can a Muslim say, "I belong to the religion of Abraham (millet-i Ibrāhìm'denim)"? This was one of the most fiercely debated questions in the Ottoman Empire in the seventeenth and eighteenth centuries. Circa 1650, the future şeyhülislām (chief jurist) Minḳārīzāde Yahyā Efendi (16o9-1678) launched a major salvo when he argued, in two pamphlets, that the practice is not permissible. 
Minḳārīzāde's second pamphlet was copied and read across the empire, stoking the flames of the dispute. Yet, a hundred years earlier, the declaration "I belong to the religion of Abraham" had been a key part of a new set of catechisms that fostered a Muslim identity centered on the sharia. What does the phrase mean and what accounts for this volte-face? How did a handful of words suddenly fall on the wrong side of the law?

The debate over the "religion of Abraham (millet-i Ibrāhim)" has a two-fold significance for our understanding of Ottoman society and Islamic law. First, it reflects the development of the confessionalization process in the early modern Ottoman Empire. ${ }^{1}$ While some scholars, discussed below, regard the debate over millet-i Ibrähìm as being about the place of non-Muslims in Ottoman society, I argue that the debate was internal to Ottoman Muslims and was about the everyday practices that signified their religious belief. The phrase, "I belong to the religion of Abraham," first emerged in the sixteenth century as part of a new set of catechisms designed to cultivate a specifically Sunni Muslim identity. In the seventeenth century, however, as more Ottoman subjects became Muslims, the standards of religiosity shifted and the phrase came to be interpreted as a denial of belief. Minḳārīzāde, in his pamphlets, argued that the words din, milla, and sharía-terms that partially connote the concept of "religion" today-have equivalent meanings. ${ }^{2}$ Declaring oneself part of the religion of Abraham therefore means ascribing Islam to Abraham and rejecting the sharia. A phrase that Muslims had used to build a confessional polity in one century became a mark of heresy in the next.

More important than the theological details of the debate over the "religion of Abraham" is the manner in which it was conducted and the audience to whom it was addressed. The polemics over the phrase offer a glimpse into what I argue to be a "popular" or, perhaps less pejoratively, "vernacular" legalism in the Ottoman Empire, i.e. the ways in which a semi-educated public received,

1 On "confessionalization" in an Ottoman context, see Tijana Krstić, Contested Conversions to Islam: Narratives of Religious Change in the Early Modern Ottoman Empire (Stanford, CA: Stanford University Press, 2011).

2 In recent years, scholars have reexamined the category of "religion" and its genealogy, often pointing out that the concept fits poorly with commonly used Arabic analogues. See, for example, Shahab Ahmed, What Is Islam? The Importance of Being Islamic (Princeton, NJ: Princeton University Press, 2016), 176-245; Brent Nongbri, Before Religion: A Histroy of a Modern Concept (New Haven: Yale University Press, 2013), 39-45; Talal Asad, Genealogies of Religion: Discipline and Reasons of Power in Christianity and Islam (Baltimore: Johns Hopkins University Press, 1993); For another point of view on the topic, see Rushain Abbasi, "Islam and the Genesis of 'Religion': A Study of Muslim Discourses on Dīn," Studia Islamica 115:1 (forthcoming 2020). The debate over millet-i Ibrāhìm can also be seen as one instance in which premodern Muslims argued over the social significance and conceptual boundaries of terms like millet and dinn. 
produced, and propagated legal debates. Participants in the vernacular legal world not only transformed the debates by introducing simplified, schematic, and polarizing readings of Islamic law, but they also created the possibility for Islamic law to become a space of public and popular politics. Vernacular legalism thus represents a social usage of the law that lies beyond its formal functions and spaces such as judges presiding in courts, jurists issuing fatwas, professors debating in madrasas, or councils reviewing appeals in divans. ${ }^{3}$ In the case of millet-i Ibrāhim, legal texts were written not to answer the question of a specific petitioner but to instigate and direct a public debate. ${ }^{4}$

The discourse of the vernacular legal world lacked the finesse or precision of traditional legal discussions, however. It was conducted at the level of the semi-educated, who could read, albeit sometimes with difficulty, but might, for instance, be unable to distinguish between the literal and figurative meaning of a phrase, a basic act of interpretation. This example raises an important distinction in my use of the word "vernacular" here. Vernacular legalism was vernacular not by virtue of its language choice, i.e. Turkish in place of Arabic, but by virtue of its partial and imperfect engagement with auxiliary sciences of language - grammar, logic, rhetoric, and disputation - that undergirded and directed legal discussions. ${ }^{5}$ Indeed, the sources on the millet-i Ibrāhim debate are primarily in Turkish, but many other similar debates of the period were conducted in Arabic, even when the scholars involved were Turkish-speaking. Regardless of the language, we find in these vernacular legal debates a desire to engage with legal arguments, though without a full grasp of the linguistic disciplines that formally trained scholars received. This understanding of the "vernacular" draws from the art historian's notion of the vernacular, as in "vernacular" architecture, i.e. common, everyday buildings built by

3 Paul Dresch has argued for a study of legalism (as opposed to law) which he defines as an "appeal to rules that are distinct from practice, the explicit use of generalizing concepts, and a disposition to address in such terms the conduct of human life." He seeks to move the study of law and society away from an emphasis on power and toward classificatory regimes. While I do not subscribe here to Dresch's overarching concept, I share an interest in using legalism to denote uses of the law outside its formal boundaries. Paul Dresch, "Introduction: Legalism, Anthropology, and History: A View from Part of Anthropology," in Legalism: Anthropology and History, ed. Paul Dresch and Hannah Skoda (Oxford: Oxford University Press, 2012), 1, 15.

4 My understanding of a "public" draws on Michael Warner, Publics and Counterpublics (New York: Zone Books, 2002). Vernacular legalism occupies a space between the local specificity of the "archive" and the abstracted universalism of the "library," to use Brinkley Messick's useful categorization of Islamic legal texts. Brinkley M. Messick, Sharīa Scripts: A Historical Anthropology (New York, NY: Columbia University Press, 2018).

5 For an overview of the heightened importance of these sciences in the seventeenth and eighteenth centuries, see Khaled el-Rouayheb, Islamic Intellectual History in the Seventeenth Century: Scholarly Currents in the Ottoman Empire and the Maghreb (New York: Cambridge University Press, 2015), esp. pp. 115-20. 
craftsmen with little or no formal academic training. Vernacular builders might draw upon dominant ideas in architecture, but often do so with their own techniques and materials or produce examples that are not meant to be canonical and exemplary. ${ }^{6}$ In spite of these shortcomings, participants in vernacular legal culture constituted an important public for legal discussions. ${ }^{7}$ This can be seen in the second iteration of Minkārizāà's pamphlet, which he shortened in an effort to make it accessible to those who found reading difficult and to fuel a debate that was smoldering in Ottoman society. The reception of the millet-i Ibrähim debate by the vernacular legal world helped convert an act of piety into a declaration of heresy. The vernacular definition of heresy often dispensed with the precise juristic distinctions between terms like kufr, ilhāad, bid'a, ghulät, and zandaqa, and almost never found its way into formal legal sources, but it remained a potent accusation.

I highlight vernacular legalism in this article to demonstrate the diverse ways in which law could take root in Muslims' daily lives. In historical studies of Islamic law, popular participation in law is often characterized as being limited to litigating affairs in a courtroom or requesting a fatwa from a mufti. ${ }^{8}$ In other

6 On the usage of the concept of vernacular architecture in art history, see N. W. Alcock and et al., "Vernacular Architecture," in Grove Art Online, 2003, https://doi.org/10.1093/gao/9781884446o54. article.To88875; this notion of the vernacular is slightly at odds with the one proposed by Sheldon Pollock, according to whom the vernacular is the realm of the local or translocal in comparison to the universal and cosmopolitan. Sheldon I. Pollock, The Language of the Gods in the World of Men: Sanskrit, Culture, and Power in Premodern India (Berkeley: University of California Press, 2009); For a discussion of the applicability of Pollock's ideas to the question of Arabic and legal discourse, see Messick, Sharia Scripts, 27-28; for a discussion of legal material in Turkish, see Sara Nur Ylldız, "A Hanafi Law Manual in the Vernacular: Devletoğlu Yūsuf Balıḳesrìs Turkish Verse Adaptation of the Hidāya-Wiqāya Textual Tradition for the Ottoman Sultan Murad II (824/1424)," Bulletin of SOAS 80:2 (2017): 283-304.

7 Steven Wilf has highlighted a "vernacular legal culture" that was specific to the American colonies in the second half of the eighteenth century (and he chooses the word "vernacular" as a more palatable alternative to "popular"). In his interpretation, vernacular legal culture is constituted by popular stories and texts about crimes and criminals that led residents of the colonies to narrativize the centrality of law to early American society. While the emphasis on the legal imagination of ordinary people is appreciated, Wilf's notion of vernacular legal culture seems to be not much more than a way of highlighting the connection between the larger cultural milieu and the significance of law, and thus I find his version of vernacular legal culture too broad to be analytically productive. Moreover, the realm of vernacular legal culture is predictably limited to criminal law. Steven Robert Wilf, Law's Imagined Republic: Popular Politics and Criminal Justice in Revolutionary America (Cambridge: Cambridge University Press, 2010), 58-66.

8 Even studies of the popular reception of law in the Ottoman Empire focus mainly on the ability of ordinary people to access legal forums like courtrooms, rather than their role in actively shaping the law. See Timothy Fitzgerald, "Reaching the Flocks: Literacy and the Mass Reception of Ottoman Law in the Sixteenth-Century Arab World," in Law and Legality in the Ottoman Empire and Republic of Turkey, ed. Kent F. Schull, M. Safa Saraçoğlu, and Zens, Robert (Bloomington: Indiana University Press, 2016), 9-25. 
words, most Muslims are regarded as consumers of law. The producers of law, by contrast, are specialists who subject themselves to years of study—not only of jurisprudence or figh, but also grammar, logic, rhetoric, and disputation. In this sense, vernacular legalism is an oxymoron given that figh is a highly specialized legal science that resists popularization. Yet, I argue that there are moments when ordinary Muslims engaged with the law, not as passive consumers but as active producers, however imperfectly. While the words of this vernacular legal world were (and still are) considered "vulgar," they represent a form of popular politics that emerged from their engagement with legal debates. To put it another way, the vernacular legal world's reception of law was also an act of the production of law and helped establish law as a space of public politics in Islamic societies.

Treating Islamic law as a popular phenomenon can, in turn, help us rewrite the history of religion in the late medieval and early modern periods. Islamic law (and forms of Islamic religiosity centered on following the sharia's prescriptions) during this period, roughly 1200-1800, is regarded as a discourse imposed by state officials or intransigent scholars onto more popular, and supposedly more authentic, forms of religious practice, such as Sufism, saint-worship, and folk beliefs, especially in frontier areas such as Anatolia and Southeastern Europe, where the power of centralized states was minimal at first. ${ }^{9}$ Indeed, Muslims rulers like the Ottomans had to recruit legal scholars from outside their realms to staff positions in their new capitals, and popular resistance to the state took the form of rebellions led by Sufis and holy men, who found a ready following among both city dwellers and nomads. ${ }^{10}$ In this context, the establishment and operation of Islamic law, along with the appointment of judges and muftis, was a projection of state power. ${ }^{11}$ Yet, efforts by the state to establish Islamic law also created a parallel, popular space of law. Although many scholars, both in the past and today, often dismissed such popular participation as

9 See, for example, James Grehan, Twilight of the Saints: Everyday Religion in Ottoman Syria and Palestine (New York: Oxford University Press, 2014).

10 Ethel Wolper, Cities and Saints: Sufism and the Transformation of Urban Space in Medieval Anatolia (University Park, Penn.: The Pennsylvania State University Press, 2003).

11 Leslie P. Peirce, Morality Tales: Law and Gender in the Ottoman Court of Aintab (Berkeley, CA: University of California Press, 2003); Guy Burak, The Second Formation of Islamic Law: The Hanafi School in the Early Modern Ottoman Empire (New York, NY: Cambridge University Press, 2015); Abdurrahman Atçl, Scholars and Sultans in the Early Modern Ottoman Empire (Cambridge: Cambridge University Press, 2017); Tijana Krstić, "State and Religion, 'Sunnitization' and 'Confessionalism' in Süleyman's Time," in Szigetvar 1566-Proceedings of the Commemorative Conference on the Siege of Szigetvar and Suleyman the Magnificent's and Miklos Zrinyi's Death, ed. Pál Fodor (Budapest: Hungarian Academy of Sciences, 2019), 65-91. 
the byproduct of preachers agitating the populace, the time has come to investigate vernacular legalism on its own terms.

This article seeks to initiate a conversation on vernacular legalism. I investigate one small example of the legal vernacular world in the seventeenth century - the debate over millet-i Ibrähim - and I engage with vernacular voices only indirectly. Many writers in the vernacular legal world lacked the authority to become authors in their own right and their presence can be discerned only through the writings of more authoritative scholars who wished either to silence or amplify their voices. I begin by explaining the rise of the practice of declaring oneself to be "part of the religion of Abraham," before turning to an examination of the pamphlets in which the debate over the practice took place. I then explain the emergence of vernacular legalism in the Ottoman context and analyze the arguments put forward by Minkāāizāde and his attempt to cultivate a particular audience of the semi-educated. Finally, I focus on the popular reception of his arguments.

The Quranic and Ottoman Origins of Abraham's Religion

The phrase "millet-i Ibrähim" has Quranic roots but it gained a new usage in the Ottoman Empire. It is taken from multiple Quranic verses, though the most commonly quoted is "say, no, [ours is] the religion (milla) of Abraham, the perennial believer."12 Abraham here is the mythic ancestor of Judaism, Christianity and Islam, and early Muslim exegetes understood his milla to be Islam, albeit a primordial religion from which Jews and Christians had ultimately deviated. ${ }^{13}$ The phrase "I belong to the religion of Abraham," or, literally, "I am [part] of the religion of Abraham (millet-i Ibrāhim'denim)," was incorporated into a new set of catechisms written in the Ottoman Empire starting in the sixteenth century. By declaring that they "belong to the religion of Abraham," Ottoman Muslims reasserted their faith as early Muslims had done when they claimed the Abrahamic legacy for themselves.

12 The translation of Qur'an 2:135 is based on that of M.A.S. Abdel Haleem, trans., The Qur'an (Oxford: Oxford University Press, 2004), 16; The full verse is: "Say, no, [ours is] the religion of Abraham the perennial believer... who did not worship any God but God." The other verses in which the phrase appears are Q2:130, 3:95, 4:125, 6:161.

13 On the meaning of milla in the classical tafāsìr literature, see Jacob Olidort, "Portraying Early Islam as the milla of Abraham: a Look at the tafsir Evidence," in The Late Antique World of Early Islam: Muslims among Christians and Jews in the East Mediterranean, ed. Robert G. Hoyland (Princeton, N.J.: The Darwin Press, 2015), 313-37. 
As Tijana Krstić demonstrates, these catechisms were intended to correct the errant practices of Ottoman Muslims, many of whom were recent converts, and to educate them in the basics of the true faith. ${ }^{14}$ The catechisms, all of which are in Turkish, often begin with a taxonomical history lesson to help guide Muslims to their proper identity. The anonymously authored Essence of Islam and Lüțî Paşa's (d.1563) Questions and Answers posed to readers a series of hypothetical questions about their proper community. Readers are told to profess that they are descendants (zürriyet) of Adam, of the religion (millet) of Abraham, of the community (ümmet) of Muhammad, and followers of the doctrine (mezheb) of Abu Hanifa. ${ }^{15}$ The so-called Spear Catechism (mizrāḳlı 'ilm-i hă $l$ ), a composite of catechisms likely compiled in the seventeenth century, starts with the following statements for the believer: "I am a descendant of Adam, I am of the religion (millet) of Abraham, I am of the faith (din) and community (ümmet) of Muhammad, the last prophet. Thanks be to God, in belief (i'tikāat) my doctrine is Sunnism (mezhebim ehl-i sünnet ve'l-cemā'at)."16 Each of these statements was a step toward a specific confessional ideal for Ottoman Muslims. The phrase "I belong to the religion of Abraham" was thus an attestation of faith, a declaration of being Muslim. Moreover, this set of attestations seems to have been a sixteenth-century Ottoman innovation: a Persian model of the question-and-answer catechism from the previous century does not include them nor mention the millet-i Ibrähim. ${ }^{17}$

Other than the pamphlets in the seventeenth century, these catechisms are nearly the only concrete demonstration of the social usage of the phrase, "I belong to the religion of Abraham." The one other example I have come across

14 Tijana Krstić, "From shahāda to 'aqüda: Conversion to Islam, Catechisation, and Sunnitisation in Sixteenth-century Ottoman Rumeli," in Islamisation: comparative perspectives from history, ed. A. C. S. Peacock (Edinburgh: Edinburgh University Press, 2017), 296-313.

15 See Biblioteca Universitaria di Bologna, MS 3324 (f. 119b) and Österreichische Nationalbibliothek MS A.F. 437 for the Ĕger sorsalar text; and see Süleymaniye Kütüphanesi, Kiliç Paşa MS 378 for the Lüțî Paşa version.

16 İsmail Kara, ed., Mızraklı İlmihal (Istanbul: Dergâh Yayınları, 1989), 5, 11, 84; Krstić, "From shahäda to 'aqïda." Given the lack of copies from before the eighteenth century, it is possible that the "Spear Catechism" was not written in the sixteenth century as is generally assumed. In later editions of the Spear Catechism, which became the standard catechism of the empire in the nineteenth century, the phrase, "I belong to the religion of Abraham," has been omitted. This suggests that the controversy had an impact on the content of the catechisms. Ismail Kara's edition of the Spear Catechism is based on the late nineteenthcentury printed versions, in which the phrase is missing, but he says he consulted earlier manuscript versions, which purportedly include the phrase. .

17 Risāle-i ìmān, Konya Bölge Kütüphanesi MS 165, ff. 119a-139b. The approximate copy date, Ashura (10) Muharram 898 A.H./ 1 Nov 1492, is taken from the colophon of the preceding treatise by the same scribe on $\mathrm{f} .116 \mathrm{~b}$. 
is in a late seventeenth-century hagiography of Demīr Bābā, a sixteenth-century holy man working in the wilds of Deliorman, in what is now northeastern Bulgaria. There, hidden in the forests, a frontier Islam that had been slowly extinguished elsewhere in the empire continued to survive. ${ }^{18}$ In one of the many stories collected about him, Demīr Bābā is summoned by the king of Muscovy to fight a dragon ravaging the land. When the infidel king asks him, "What is your religion (ne milletdensün)," he answers "I belong to Abraham's religion."19 What exactly he means by this is unclear. While he may be stating that he is a Muslim, the phrase could have had different connotations for him altogether. Regardless, the phrase "I belong to Abraham's religion" functions as a declaration of belief or identity. When the king asks Demīr Bābā if he is referring to the Abraham who freed Nimrod, Demīr Bābā answers in the affirmative. The answer is odd, given that Nimrod is Abraham's primary antagonist in the Qur'an and in stories about the prophets, but it suggests that there was a large and diverse popular lore about Abraham's central role in the origins of Islam..$^{20}$ The authors of the sixteenth-century catechisms may have drawn upon this popular devotion to Abraham when they made the declaration "I belong to the religion of Abraham" one of the foundations of Ottoman Muslim identity. These examples demonstrate that the millet-i Ibrähim was not a discrete religious community, but rather a pious and frequently uttered declaration. As the seventeenth-century bibliophile Kātib Çelebi (16o9-1657) noted, "it has become a widespread and regular habit among the people to say simply 'I belong to the religion of Abraham."'21 Utterance of the phrase was one of the many everyday practices that constituted lived religion in the Ottoman Empire. $^{22}$

18 On the dating of the text, see Nikolay Antov, The Ottoman "Wild West:" The Balkan Frontier in the Fifteenth and Sixteenth Centuries (Cambridge: Cambridge University Press, 2017), 207-8.

19 Filiz Kılıç and Tuncay Bülbül, eds., Demir Baba Velâyetnâmesi (Ankara: Grafiker Yayınları, 2011), 91; Antov, The Ottoman “Wild West," 233. I thank Nikolay Antov for bringing this story to my attention.

20 A popular Persian couplet that mentions Abraham as the builder of the Ka'ba is found on manuscripts and ceramics throughout the sixteenth and seventeenth centuries. For a Ka'ba tile example, see the David Collection, Inv. No. 51/1979. For examples of the couplet's usage, see Sabiha Göloğlu, "Depicting the Holy: Representations of Mecca, Medina, and Jerusalem in the Late Ottoman Empire” (unpublished Ph.D. dissertation, Istanbul, Koç University, 2018), 55-56. The couplet was the subject of a fatwa by Ebü's-su'üd regarding whether it is permissible to call Abraham Halīl-i Āzar. See Universiteitsbibliotheek Leiden, MS Or. 12425 f. 2 a.

21 Kâtib Chelebi, The Balance of Truth, trans. G. L. Lewis (London: George Allen and Unwin Ltd, 1957), 121.

22 On the recent turn to conceiving religion as constituted by "everyday" practices, see Nancy T. Ammerman, "Finding Religion in Everyday Life," Sociology of Religion 75:2 (2014): 189-207. 
Although the phrase millet-i Ibrähim was introduced as part of an effort to cultivate a specific confessional identity in Ottoman Muslim subjects, it possessed some inherent ambiguities that made it a source of controversy. The first is the reference to Abraham/Ibrāhīm. By linking an Ottoman Islamic identity to the first prophet of Judaism, Christianity, and Islam, the catechisms opened the possibility of blurring the distinction between the different faiths. In the pre-Islamic and early Islamic periods, this shared heritage created a dilemma for the Prophet Muhammad as he sought both to align his religion with and differentiate it from the hanifiyya or din Ibrähim, the general monotheism in the Arabian lands centered on the figure of Abraham. ${ }^{23}$ The Ottoman-era debate over millet-i Ibrähìm bears no connection to this early Islamic discussion regarding the hanifiyya; the debate was not over the interpretation of the Quranic verse ("say, no, [ours is] the religion of Abraham, the perennial believer") but over the catechismic declaration, "I belong to Abraham's religion," which does not include the additional description of Abraham as a haniff. However, the Ottoman-era declaration raised questions similar to those that the Quranic verses raised for early Muslims. For Minkārīzāde, Muslims who declare that they "belong to the religion of Abraham" implicitly call into question the relation between Muhammad and Abraham and between Islam and its Abrahamic precursors. An inherent tension has always lurked in the millennia-long debate over Abraham's legacy: recognizing familial resemblances can quickly become the impetus for a family feud. ${ }^{24}$ Today, this discussion continues in the newly coined concept of "Abrahamic religions;" Abraham is no longer an object of competition but a figure through whom we envision a shared future. ${ }^{25}$

The other ambiguity in the phrase millet-i Ibrāhim lies in the many significations of the word millet. Historians of the Ottoman Empire today understand millet to signify a community of people connected to a specific religion, almost invariably non-Muslim. The phrase millet-i Ibrähim thus suggests to the ear of

23 Uri Rubin, "Hanifiyya and Ka'ba: an inquiry into the Arabian, pre-Islamic background of din Ibrāhìm," Jerusalem Studies in Arabic and Islam 13 (1990): 85-112; see also Olidort, "Portraying Early Islam as the milla of Abraham."

24 Guy G. Stroumsa, "From Abraham's Religion to the Abrahamic Religions," Historia Religionum 3 (2011): 11-22.

25 Stroumsa, 20. In recent years, scholars have criticized the use of "Abrahamic religions" as an analytical concept. See Aaron W. Hughes, Abrahamic Religions: On the Uses and Abuses of History (Oxford: Oxford University Press, 2012); Jon D. Levenson, Inheriting Abraham: The Legacy of Patriarch in Judaism, Christianity, \& Islam (Princeton, N.J.: Princeton University Press, 2012); Guy G. Stroumsa, The Making of the Abrahamic Religions in Late Antiquity (Oxford: Oxford University Press, 2015). 
the modern historian a community of Jews or an interconfessional community. ${ }^{26}$ Yet, in the past, millet signified much more than our modern notion of a religious community. As seen in the aforementioned catechisms from the early modern period, millet was often treated as a synonym of din (religion, faith), but it was also unclear how precisely it differed from itikäa (belief) or ümmet (community). Similarly, in modern translations of the Qur'an, milla is alternately rendered as "religion," "community," and "law."27 Minkārīzāde would use the ambiguity inherent in the word to extend the signification of millet to encompass the sharia.

The ambiguous associations of those two words, millet and Ibrähim, have hampered the efforts of the few historians who have touched upon the Ottoman-era debate. Cengiz Şişman, for example, argues that Minḳārīzāde wrote his millet-i Ibrāhim treatise to preserve more tolerant classical attitudes toward non-Muslims in the face of attacks on Jews and Christians. ${ }^{28} \mathrm{He}$

26 Part of the modern confusion over the term millet-i Ibrāhim derives from our modern notion of millet as proto-nation, as in the so-called "millet system." That meaning emerged in the eighteenth century as the Ottoman government introduced an official relationship between the government and the religious leaders it appointed to represent non-Muslim communities. Benjamin Braude, "Foundation Myths of the Millet System," in Christians and Jews in the Ottoman Empire: The Functioning of a Plural Society, Vol.1: The Central Lands, ed. Benjamin Braude and Bernard Lewis (London: Holmes \& Meier, 1982), 69-9o; Daniel Goffman, "Ottoman Millets in the Early Seventeenth Century," New Perspectives on Turkey 11 (1994): 135-58; Paraskevas Konortas, "From Taife to Millet: Ottoman Terms for the Ottoman Greek Orthodox Community," in Ottoman Greeks in the Age of Nationalism, ed. Dimitri Gondicas and Charles Issawi (Princeton, NJ: Princeton University Press, 1999), 169-79; Maurits H. van den Boogert, "Millets: Past and Present," in Religious Minorities in the Middle East: Domination, SelfEmpowerment, Accomodation, ed. Anh Nga Longva and Annie Sofie Roald (Leiden: Brill, 2012), 27-45; Antonis Hadjikyriacou, "Beyond the Millet Debate: Communal Representation in PreTanzimat Cyprus," in Halcyon Days in Crete ix: Political Thought and Practice in the Ottoman Empire, ed. Marinos Sariyannis (Rethymno: Crete University Press, 2019), 71-96; One of the few Ottomanists who recognized millet as religion is M. O. H. Ursinus. See $E I^{2}$, s.v. Millet (Ursinus).

27 Olidort, "Portraying Early Islam as the milla of Abraham," 315.

28 Cengiz Şişman, "Minkarizâde Yahya: Şeyhülislam Minkarizâde Yahya Efendi," in ChristianMuslim Relations: A Bibliographic History: Volume 10: Ottoman and Safavid Empires (160o1700), ed. David Thomas and John Chesworth (Leiden: Brill, 2017), 404-10; Harun Küçük interprets the fatwa of Yenişehirli 'Abdullah Efendi, mentioned below, in a similar manner. He suggests that Sultan Ahmed II instructed the şeyhülislām to forbid Muslims from saying that they "belong to the millet-i Ibrähim," and instead to say that they "belong to the millet-i Muhammad." The goal of the change was to create a more equal and inclusive status for nonMuslim subjects, that is, the millet-i Ibrāhim. This suggestion does not make much sense. Why should Muslims, in a more equal system, not be allowed to state that they belonged to the millet-i Ibrähìm, especially as we have no examples of non-Muslims referring to themselves in this manner. Bekir Harun Küçük, "Early Enlightenment in Istanbul" (unpublished Ph.D. dissertation, La Jolla, Calif., University of California, San Diego, 2012), 22. 
suggests that Minkāāīzāde wrote his treatise in response to a purportedly fundamentalist movement called the Kạḍīzādelis, discussed below. In particular, Şişman proposes that Minḳārīzāde was responding to one of the Kādīzādeli preachers, Vānī Meḥmed Efendi (d. 1096/1685), who, alongside Minḳārīzāde himself and Kara Mușțafā Paşā (d. 1095/1683), oversaw the trial and conversion of the Jewish messiah claimant Sabbatai Zevi in 1666. ${ }^{29}$ Şişman assumes, one, that the Ottoman-era debate over millet-i Ibrähim is connected to the aforementioned discussion of haniffs, the followers of the pre-Islamic Arabian monotheism, and, two, that, because it uses the word millet, it should relate to the status of non-Muslims. This is incorrect. While the early Islamic interpretations of the term millat Ibrāhìm connected it to the hanīfs, Minkārīzāde and others' treatises on the topic do not discuss the hanifyya in any way. Moreover, the debate is not about the status of non-Muslims nor was Minkārīzāde trying to uphold some sort of tolerance toward non-Muslims; ${ }^{30}$ Minḳārīzāde's treatise mentions neither Jews nor Christians, as Şişman himself acknowledges. The

29 Minḳārīzāde's role in the trial of Sabbatai Zevi is elaborated in Cengiz Şişman, The Burden of Silence: Sabbatai Sevi and the Evolution of the Ottoman-Turkish Dönmes (New York, NY: Oxford University Press, 2015), 30-34.

30 Şişman's contention that Minkāāizāde held more tolerant views of non-Muslims follows from a compounded overinterpretation of an anecdote recounted by Paul Rycaut (d. 1700), an English diplomat living in Istanbul in the 166os, regarding a disagreement between Minkāāīāde Yahyāa and Vānī Meḥmed. The topic at hand was whether communal prayers in support of the Ottoman armies' campaigns against the Habsburgs in 1664 should be held in a city-wide assembly or in mosques. Minkāāizāde and another shaykh, basing themselves on legal precedent and tradition, argued for the former, while Vānī argued for the latter. According to Rycaut's account of the event, the controversy was about whether or not a citywide assembly increased the efficacy of the prayer. Vānī argued that since all participants were true Muslims ("Believers"), a citywide assembly was a superfluous addition. In her article on the Kādīizādeli movement, Madeline Zilfi interprets this episode as part of Vānī’s attack on religious syncretism (presumably, non-Muslims could participate in a citywide mass prayer) and Sufism (she assumes that Minḳārīzāde's supportive shaykh was a Sufi). Şişman interprets Zilfi's comments as proof that Minḳārīzāde completely opposed Vānī and the Kādịzādelis and therefore Minḳārīzāde had a "disdain of the anti-Jewish and anti-Christian sentiments on the rise during this period" and wrote the treatise on millet-i Ibrähìm to counter such beliefs. Both Zilfi and Şişman may have overinterpreted a single report by an English diplomat; While Vānī may have had a larger intention in arguing that city-wide communal prayers were not efficacious, Minkārīzāde's opposition to Vānī's position does not necessarily mean that he held more tolerant views of non-Muslims, only that, in this instance, he adhered to legal precedent and fought for the superiority of his views at court. Paul Rycaut, The History of the Turkish Empire from the Year 1623 to the Year 1677, 2 vols. (London, 1680), 2:154. Madeline Zilfi, "The Kadizadelis: Discordant Revivalism in Seventeenth-Century Istanbul," Journal of Near Eastern Studies 45:4 (1986), 251-69, comment on Minḳārīzāde at 264-5; Şişman, "Minkarizâde Yahya," 407. 
work is also not an argument against the Kāḍizzādelis. ${ }^{31}$ While the Kăḍizzādelī framework very poorly explains the religious dynamics of the seventeenth century, if one were to measure Minkāarizāde by its standards, his ideas would fall close to those of Vānī Mehmed. Moreover, the date of Minkārīzāde's treatise makes it highly unlikely that he was responding to Vānī Mehmed Efendi, who arrived in Istanbul and assumed a position of power in the court only in 1662, years after Minḳārīzāde wrote his work.

Şişman's argument aside, the Kâdịizādeli movement remains the main framework through which scholars interpret the polemical debates of the seventeenth century, like the dispute over the religion of Abraham. ${ }^{32}$ According to this narrative, a few puritanical preachers tapped into the economic frustrations of Istanbul's denizens to further their own extremist agenda. A so-called "fundamentalist" movement emerged, in which practices like coffee drinking, tobacco smoking, and Sufi rituals were attacked as "innovations." However, the movement quickly dissipated with the dismissal of Vānī Mehmed Efendi following the failed siege of Vienna in 1683 .

Rather than seeing the polemical debates as emerging from a paroxysm of fundamentalism, it is more helpful to situate them in the process of "confessionalization" and "Sunnitization" that Tijana Krstic and Derin Terzioğlu have recently elaborated. ${ }^{33}$ Confessionalization in the Ottoman context entailed a long-term alignment of the empire's identity with a specifically Sunni and Hanafi Islam. The confessional identity of Ottoman subjects had been of minor concern to Ottoman rulers before the fifteenth century. Even seemingly basic beliefs like the superiority of the Prophet Muhammad over the other prophets, or that the five canonical prayers were obligatory, could not be taken for granted; there are reports that in late fourteenth-century and early fifteenth-century Bursa, some Ottoman Muslims regarded Jesus as the most superior Prophet. ${ }^{34}$ In the words of Cemal Kafadar, there reigned a

${ }^{1}$ Şişman bases his claim that the debate over the "religion of Abraham" is tied to the Kâḍīzādelis on a reference to Madeline Zilfi's article on the movement. Zilfi, in turn, bases her connection of the two events on the fact that Kătib Çelebi includes the controversy in his book about the debates of the period, The Balance of Truth (Mizānu'l-hakk). However, not every debate in The Balance of Truth should be read as part of the Kāạīzādeli agenda. Kātib Çelebi lists public and popular debates that he felt were ignited by the participation of the uneducated. Zilfi, "The Kadizadelis," 255; Kâtib Chelebi, The Balance of Truth, 108-23.

Zilfi, "The Kadizadelis;" Madeline Zilfi, The Politics of Piety: The Ottoman Ulema in the Postclassical Age (1600-180o) (Minneapolis, MN: Bibliotheca Islamica, 1988).

33 Krstić, Contested Conversions to Islam; Derin Terzioğlu, "How to Conceptualize Ottoman Sunnitization: A Historiographical Discussion," Turcica 44 (2012-2013): 301-38.

34 Baki Tezcan, "Ottoman Mevali as 'Lords of the Law," Journal of Islamic Studies 2:3 (September 2009): 384-85. 
"metadoxy" in the early Ottoman Empire, a state of confessional ambiguity in which neither orthodoxy nor heterodoxy was fully articulated..$^{35}$ There were initial attempts at confessional boundary-making within the empire in the fifteenth century, but the process did not begin in earnest until the sixteenth century when it was triggered by imperial competition with the Safavids and their Kuzllbaş followers in the east and Catholic rulers in the west. The catechisms that incorporated the phrase "millet-i Ibrähim" were only one part of a series of changes that included organizing neighborhoods around the disciplinary watch of mosques, educating Muslims in the basic legal requirements of Islam, and the introduction of new ideas about heresy. ${ }^{36}$ The framework of confessionalization has proven to be particularly fruitful for scholars studying the Ottoman Empire because it allows them to treat religion in general, and Sunnism in particular, as an evolving entity. This point may appear self-evident but it makes a needed intervention in earlier scholarship, like that on the Kaaḍizādeli movement, which treats religion as a set of fixed "orthodox" Islamic beliefs that are either adopted or set aside.

The polemical debates over millet-i Ibrähim were one manifestation of the confessionalization process in the sixteenth and seventeenth centuries, as more and more of the empire's Muslim population introduced daily prescribed Islamic actions into their lives. Tijana Krstić explains this process in regard to the Süleymanic period: "authors [of catechisms] explicitly circumscribed the field of piety for Ottoman Muslims by erecting ever more numerous signposts beyond which the domain of infidelity began, while at the same time promoting $f i k i h$ and its practitioners as the ultimate arbiters of the boundaries of belief." 37 Standards of piety shifted as Ottoman subjects became familiar with the requirements and proofs of the sharia. Daily actions that had once been acceptable, like declaring that one belonged to the religion of Abraham, were suddenly subject to greater scrutiny and became the object of popular debate.

Minḳārīzāde’s Pamphlets

Minkārīzāde's two pamphlets on millet-i Ibrāhìm are our chief sources on the controversy over the phrase and therefore we have to delve into the

35 On metadoxy, see Cemal Kafadar, Between Two Worlds: The Construction of the Ottoman State (Berkeley: University of California Press, 1995), 76.

36 See the essays in Tijana Krstić and Derin Terzioğlu, eds., Historicizing Sunni Islam in the Ottoman Empire, c. 1450-c. $175^{\circ}$ (Leiden: Brill, 2020).

37 Krstić, "State and Religion," 84. 
Minkārīzāde's motivation for writing them. ${ }^{38}$ Both of his pamphlets are written in Turkish: the first pamphlet is about fifteen to twenty folios and the second, an abridgement of the first, is about two or three folios, depending on the copyist. It is this second, shorter pamphlet that made its way across the empire and prompted a number of responses.

Minḳārīzāde Yahyā Efendi was the son of the eponymous Minkāāī Ömer Efendi (minkāri likely refers to an aquiline or hook nose), a provincial scholar who became a successful professor in the capital and was eventually appointed the chief judge of Mecca, where he died when Minḳārīzāde was fifteen years old. ${ }^{39}$ The son drew upon his father's scholarly connections to study Qur'an recitation as a child with the famous Sufi shaykh Hüdāī Mahmūd Efendi (d. 1628 ), and after quickly completing a madrasa education, studied with his eniştes (the husbands of his aunts, a special role of mentor and protector in Turkish culture)—Veli Efendi and şeyhülistām 'Abdurrahīm Efendi (d. 1656). ${ }^{40}$ Minkārīzāde went on to teach at several madrasas until he was appointed to higher imperial positions, taking up the chief judgeship of Mecca in 1649; in 1652 he was appointed as chief judge of Egypt, where he established close contacts with Arab scholars and continued to hold teaching sessions at local madrasas and the governor's court. ${ }^{41}$ Like many officials in high positions, he held this post intermittently, being appointed and dismissed three times. In 1658 , he was briefly appointed chief examiner of the 'ulemā for a few months before becoming chief judge of Istanbul. In 1662, he became Rumeli kazasker, and a few months later he reached the top of the pyramid when he became şeyhülislām, a position he held for eleven years, achieving a level of power and influence that few şeyhülislāms ever attained. At the height of his career,

38 For this article I examined some forty copies of this treatise in manuscript libraries around the world (though many more exist and are not cataloged properly). I also acquired reproductions of early copies from the following libraries: İstanbul Üniversitesi Nadir Eserler Kütüphanesi MS T5917; Harvard University, Houghton Library, MS Arab 292 ff. 99a-101a; UCLA Young Research Library Special Collections, Collection 896, Box 109, MS 740; İstanbul Araştırma Enstitüsü, Şevket Rado MS 232 ff. 132b-136b; Gazi Husrev-Begova Biblioteka, MS R702 ff. 198b-204b; Beyazıt Devlet Kütüphanesi, Veliyüddin Efendi MS 1064 ff. 166-168; Princeton University Library, Garrett MS. 40oL. The long version of the pamphlet can be found in Nuruosmaniye Kütüphanesi, MS 4952 ff. 25b-54a and in Süleymaniye Kütüphanesi, Yazma Bă̆ışlar MS 1438 ff. 103-116.

39 Nev'izâde Atâyî, Hadâ'iku'l-hakâik fî tekmileti'ş-şakâ'ik: Nevi'îzâde Atâyînin Şakâik zeyli, ed. Suat Donuk and Derya Örs, vol. 2 (İstanbul: Türkiye Yazma Eserler Kurumu Başkanlığı, 2017), 1709-10.

40 Şeyhî Mehmed Efendi, Vekâyi'u'l-fuzalâ: Şeyhînin Şakâik zeyli, ed. Ramazan Ekinci and Derya Örs, vol. 2 (İstanbul: Türkiye Yazma Eserler Kurumu Başkanlığı, 2018), 1128-29.

41 Şeyhî Mehmed Efendi, 2:1129; Muḥammad Amīn b. Faḍl Allāh al-Muhịbīi, Khulāṣat al-athar fì àyān al-qarn al-hāà 'ìshar, vol. 4 (Cairo, 1284), 477-78. 
however, something afflicted his right hand, rendering him unable to write and continue working, and he was dismissed in $1673 .{ }^{42}$ His many writings, most of which were likely completed in the 165 os, included a tertiary commentary on al-Baydawì's (d. 1286) interpretation of the Qur'an and a work of disputation theory (adab al-bahth) written as a tertiary commentary on Mīr Abi'l-Fath's (d. 1568) commentary on al-Adab al-Adudiyya. His popular pamphlet on millet-i Ibrāhim was also penned in this period, though his biographers fail to mention it, possibly due to the fact that it was aimed not at scholars but at the general public.

Minkāiāzāde's second pamphlet was the most popular work on the millet-i Ibrāhim controversy in the Ottoman period; today, however, students of Ottoman history who might have heard of the "religion of Abraham" are more familiar with Kātib Çelebi's description of the controversy from The Balance of Truth. Kātib Çelebi's genius lies in his capacity to compile and collect, not in original thought: his chapter on millet-i Ibrähim is almost completely comprised of anonymized quotations from Minkāāizāde's longer treatise. Unlike the other scholars to whom he refers by name in his book, Kātib Çelebi anonymizes his extended quotations from Minḳārīzāde, refer-

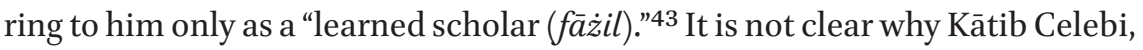
who was so eager to highlight the sagacity of his friends and the stupidity of his enemies, does not mention Minkārīzāde by name. Perhaps it is because he regarded Minkāinizāde to be an opportunist like his own former teacher, Ḳậīizāde Meḥmed. The eponymous "founder" of the Kāẹīzādeli movement was an incendiary with a sharp mind who courted controversy for personal gain, according to Kātib Çelebi. ${ }^{44}$ The rest of Kātib Çelebi's treatise contains a disparaging summary of a certain unknown shaykh's (referred to as şeyh-i mücīb or the respondent shaykh ${ }^{45}$ ) defense of declaring oneself part of the religion of Abraham and Kătib Çelebi's summation that while the masses are ultimately wrong, it is futile to try to stop them.

42 Modern scholars have interpreted this illness as a stroke, though the sources are ambiguous on the matter.

43 One reason why Kātib Çelebi's copying activities were not readily recognized was that the translator, Lewis, decided to render "fäzill," or "scholar," as a proper name and not as a descriptor. He also found Kātib Çelebi's treatment of the topic tedious. Kâtib Chelebi, The Balance of Truth, 12, 110.

44 Kātib Çelebi, Mīzānü'l-hakk fi ihtiyāri'l-ahakk (Ḳosțanținniye: Mațba'a-i Ebu'l-Żiyā, 13o6), 132; Kâtib Chelebi, The Balance of Truth, 137.

45 The translator of Kātib Çelebi's work, Lewis, read mücīb as the name of the shaykh (as he did with the descriptor fäzil above), but Mücib as a name is rare and nearly always found in compounds with a name of God, not by itself. It likely refers to a respondent in this case. I thank the anonymous reviewer for pointing this out. 
In The Balance of Truth, Kātib Çelebi includes the millet-i Ibrāhìm controversy as one of twenty-one debates over proper Muslim practice-such as the permissibility of worshipping at the tombs of saints or smoking tobacco-that smoldered in the empire during the seventeenth century. Of course, there were more than twenty-one debates and most were fought in what I call "pamphlets:" short and cheap treatises that brought legal debates and proofs to a vernacular and popular audience. ${ }^{46}$ Pamphlets provided readers with a hadith or two, some quotes from a major legal scholar like al-Bayḍawī, and perhaps some counterarguments to deploy against anyone who disagreed. They gave access to legal argumentation to those who lacked the intellectual or financial capacity to navigate large legal manuals. Most are written in a straightforward and accessible Arabic or, on a rare occasion, in Turkish, as in the case of Minkārīzāde's pamphlet. In other words, the vernacularity of the pamphlets resides not only in their choice of language, but also in opening legal argumentation to a popular audience, as will be discussed below.

Most of the topics discussed by Kātib Çelebi have left behind a long trail of pamphlets, evidence of the vigorous and contentious debates they inspired. The millet-i Ibrähim debate is anomalous in that it is dominated by single pamphlet by Minḳāīzāde; it is difficult to find treatises other than his and what exists almost always refers back to his treatise. The controversy over the phrase "I belong to the religion of Abraham" appears to have started in the early seventeenth century. Writing in 1656, Kātib Çelebi points out that over eighty treatises recently had been written on millet-i Ibrāhim, nearly none of which has survived today. ${ }^{47}$ By contrast, what remains besides Minḳāīzāde’s pamphlets and Kātib Çelebi's summary are a few direct responses to Minḳārīzāde's claims, of which only two are extant. Kātib Çelebi also mentions that the government tried to ban usage of the phrase (taraf-ı saltanatdan men' olunsa), yet traces of this attempt are difficult to find. ${ }^{48} \mathrm{He}$ may be referring to a fatwa that supposedly was penned by şeyhülislām Meḥmed Bahā'ī Efendi (r. 1649-1651,

46 What I call "pamphlets" are referred to as risāla / rasāil (pl.) in Arabic and risāle / resāil or risāleler (pl.) in Turkish, literally, a treatise. However, a risāla can refer to a text that ranges from hundreds of folios to a few folios. I use the word "pamphlet" to differentiate the short, ephemeral treatises that were the main medium for these seventeenth-century polemical debates from a generic risāla. See my forthcoming monograph, Pamphleteering Islam, for more information.

47 Kâtib Chelebi, The Balance of Truth, 121. There are two copies of an anonymous treatise in Arabic that do not respond to Minkāinizāde's piece and that may therefore predate his treatise. See Beyazıt Devlet Kütüphanesi, Veliyüddin MS 1064, ff. 204a-205b; Süleymaniye Kütüphanesi, Mihrişah Sultan MS 22o, ff. 368a-369b.

48 Kātib Çelebi, Mìzānü̈l-hakk fi ihtiyāri'l-ahakk, 114. 
1652-1654), of which I have found only a single copy, scribbled at the end of Minkārizzāde's treatise: "When Zeyd asks 'Amr the Muslim, 'Which millet do you belong to?' how must 'Amr respond?" The şeyhülistām answers that "it is sufficient to say that "I follow (üzereyim) the din of the Prophet Muhammad." In this legal opinion, the şeyhülisläm provides a valid answer but evades the larger question looming in the background, that is, whether or not it is permissible to say "I belong to the religion (millet) of Abraham." Instead, he falls back on the formula that Muslims should state that they follow the religion (din) of Muhammad.

Despite the fact that Kātib Çelebi alluded to the existence of over eighty pamphlets on the topic of millet-i Ibrāhim, the number of extant copies of Minkārizzāde's second, shorter pamphlet radically exceeds that of all other texts on the topic in the manuscript record. This numerical domination can be partially explained by the fact that Minkārīzāde crafted it to circulate and be read by a large public. We can tell that he wanted to use pamphlets to instigate a more popular class of readers to action because he tried twice to get it right. He most likely completed his pamphlets between $165^{2}$ and 1655 , when he was moving back and forth between Cairo and Istanbul during his appointments as chief judge of Egypt. The timing is significant because it demonstrates that he was not yet a şeyhülisläm, with the power of the state behind him, when he wrote the treatise. Instead, he was between jobs, perhaps trying to find a way of cultivating power outside of formal positions. Circa 1652, he wrote the longer pamphlet, the one from which Kătib Çelebi copied heavily. ${ }^{50}$ Unlike his other writings, which are nearly all in Arabic, he chose to write in Turkish, presumably to reach a specific audience of Turcophone Ottoman Muslims whose Arabic was shaky. Apparently, this work failed to reach its intended audience. He therefore composed a second, shorter version by removing "ancillary arguments (şi'ab)" so that "reading (muțāla'a) it would not tire its readers;" 51 fifteen

49 İstanbul Araştırma Enstitüsü, Şevket Rado MS 232 f. 136b

50 The earliest dated copy of the longer pamphlet that I have found is from ca. 1 Feb 1665 (middle of Rajab 1075). It was copied from the author's "second copy" and from another copy that was collated against the author's original, Nuruosmaniye Kütüphanesi MS 4952 ff. 25b-54a. The earliest version of the shorter pamphlet is from July 4, 1656 (12 Ramazan 1066) in İstanbul Üniversitesi Nadir Eserleri Kütüphanesi, MS T5917. In his Balance of Truth, written in 1656, Kātib Çelebi uses the longer pamphlet but does not mention the shorter one. This suggests that Minḳārīzāde's longer pamphlet had been circulating since ca. 1652 and that the shorter one was written in 1656 , or a year or two earlier.

$5^{1}$ Minḳārīzāde refers to the act of reading with the term "muțālaca," which, alongside nazar, is one of the common words used to refer to reading at the time. Significantly, the use of muțālac $a$ conveys the fact that pamphlet was intended to be read alone and visually, rather than recited to a group. 
to twenty folios were reduced to two or three. ${ }^{52}$ As we shall see below, this second attempt at writing a pamphlet proved to be a success. Not only were many more copies made-I have come across only two or so copies of the longer pamphlet compared to around a hundred copies of the shorter one-but Minkāāizāde was able to tap into a popular audience, one that had difficulty reading but still wanted to participate in these debates. Minkārīzāde's second pamphlet on millet-i Ibrāhim proved to be so popular that it overshadowed all other pamphlets and set the terms of the debate.

\section{3}

\section{Vernacular Legalism}

Who were these enthusiastic, but easily exhausted, readers of Minḳārīzāde? They likely belonged to a group known as ümmis, a semi-educated population, linguistically grounded in Turkish but perhaps aspiring to read and write in Arabic. ${ }^{53} \ddot{U m m i}$ is often translated as "illiterate," but this rendering overlooks other significations of the word. In the Qur'an, ummi "appears as the counter-image of those who claim exclusivity or superiority by virtue of their possessing Scripture and scribal knowledge," and it refers to anyone "whose scriptural knowledge is limited." ${ }^{44}$ In the late medieval and early modern periods (1200-180o), the term continued to hold the same connotations, except that it referred not to a lack of scriptural knowledge but to a lack of knowledge derived from education. ${ }^{55}$ Ümmis possessed only a partial education or even eschewed the conceits of education out of modesty, as did the many Sufis and poets in the fifteenth and sixteenth centuries who added the term ümmi to

52 Minḳārīzāde, Risāle-i millet-i Ibrāhīm, Beyazıt Devlet Kütüphanesi, Veliyüddin MS 1064 f. 166b.

53 On ümmi readers, see Derin Terzioğlu, "Where Ilm-i Hal Meets Catechism: Islamic Manuals of Religious Instruction in the Ottoman Empire in the Age of Confessionalization," Past \& Present 220 (2013): 79-115, at 90-91; and S. Aslhhan Gürbüzel, "Teachers of the Public, Advisors to the Sultan: Preachers and the Rise of a Political Public Sphere in Early Modern Istanbul (16oo-1675)," Ph.D. Dissertation, Harvard University, 2016, 180-89.

54 Islam Dayeh, "Prophecy and Writing in the Qur'an, or Why Muhammad Was Not a Scribe," in The Qur'an's Reformation of Judaism and Christianity: Return to the Origins, ed. Holger M. Zellentin (Abingdon, Oxon: Routledge, 2019), 55 .

55 Emine Gürsoy-Naskali, "Yunus Emre ve edebiyat tarihçileri," in Yunus Emre sempozyumu: Bildiriler (İstanbul: Marmara Üniversitesi Yayınları, 1992); John Curry, The Transformation of Muslim Mystical Thought in the Ottoman Empire: The Rise of the Halveti Order, 1350-1650 (Edinburgh: Edinburgh University Press, 2010), 127-28; Dana Sajdi, The Barber of Damascus: Nouveau Literacy in the Eighteenth-Century Ottoman Levant (Stanford, Calif.: Stanford University Press, 2013), 43. 
their names. It also could signify a person who could read but not write, or who could read Turkish but not Arabic. These men probably saw themselves as more educated than ordinary people ('avāmm), albeit not at the level of the learned elite (hāvașs). Despite these limitations, they remained an audience that could be cultivated in the sixteenth to eighteenth centuries.

Some ümmis likely resembled the anonymous shaykh whom Kātib Çelebi thoroughly disparaged in his essay on millet-i Ibrähìm:

This respondent wrote a treatise in Arabic, weak in matter and composition, beginning with a few roughly-drafted lines purporting to be addressed to the Sheykh al-Islam. I have thought it desirable to omit them, as they are a mass of immoderate confutations and inventions. After that, the treatise is a jejune compilation of Koranic verses and traditions relating to religion and faith, the superficial meaning being given every time. From these he ostensibly draws conclusions and with tremendous foolhardiness shows no respect or regard for the words of commentators or theologians, not understanding what any given scholar's argument is or on what it is based, or whether it is refutable. ${ }^{56}$

Kātib Çelebi's invective highlights the characteristics of "bad" readers and writers. First, their inability to differentiate between literal and figurative meanings (zāhirī üzere ma'nālar vèrüb) reflects a lack of knowledge of rhetoric, balāgha. Likewise, something "weak in matter and composition $(\dot{z} a f-i$ te'lif ü terkīb)," i.e. that it is poorly written, suggests a deficiency on the part of the writer in both rhetoric and grammar, nahw. The inability to understand an argument and "whether it is refutable (red ve men' kabülèder mi bilmiyüb)" reveals an ignorance of the rules of disputation, adab al-bahth, and logic, mantiq. Finally, the refusal or inability to refer to authorities on the topic (ehl-i tefsìr ve 'ülemā-i ușūl sözlerine i'tibār ve iltifāt eylemiyüb) makes it clear that these $\ddot{m} m m i s$ were unable to engage in scholarly debates. ${ }^{57}$ The anonymous shaykh was a proponent of Muslims' declaring their belonging to the millet-i Ibrähim, but the criticism held true for both proponents and opponents of the practice.

Vernacular legalism encouraged, or at least tolerated, the forms of reading described above. Due to their lack of mastery of the auxiliary sciences of language, ümmis preferred literal over non-literal interpretations and often failed

$5^{6}$ Translation taken from Lewis, The Balance of Truth, 117; Kātib Çelebi, Mīzānül-hakk fi ihtiyāril-ahakk., 108-9.

57 Kātib Çelebi, Mizzānül'-ḥaḳk fi ihtìyāri'l-ahakk, 108-9. 
to respond to arguments with valid proofs. Again, what made these readers "vernacular" was not their choice of language necessarily, but the methods with which they approached texts. The choice of language did not translate directly to a broader or more restricted audience. Many historians presume that a text written in Arabic would have had a smaller audience in the Ottoman Empire, but many vernacular writers and readers, like the anonymous shaykh above, seemed to have preferred Arabic, even if their command of the language was weak. Choosing to write in Turkish, as Minkārīzāde did, might broaden the potential audience of a text, but it also potentially changed its interpretation. Few, if any, works on rhetoric, disputation, logic, and even grammar existed in Turkish and so Turcophone readers without training in these linguistic sciences lacked the interpretive precision associated with legal scholarship and debate. ${ }^{58}$ Vernacular readers worked with legal texts not as scholars evaluating the formal validity of the arguments, but as debaters eager to take arguments and counterarguments to the street, mosque, and coffeehouse. It was precisely this middling audience that Minkārīzāde attempted to tap.

While vernacular legalism may have emerged in other Islamic societies, developments in the Ottoman Empire made it especially salient there. First, the confession-building policies of the sixteenth century encouraged Ottoman Muslims to practice Islam according to the standards of sharia and to measure their religiosity accordingly, thereby promoting a popular desire for legal knowledge..$^{59}$ Moreover, in the fifteenth and sixteenth centuries the Ottoman government had attempted to monopolize the legal field, taking what had been a largely decentralized community of jurists and instituting a state-appointed hierarchy ${ }^{60}$ In the seventeenth and eighteenth centuries, the Ottoman state took a more prominent role in defining and regulating the rulings of jurists and judges. ${ }^{61}$ These processes were always partial and contested, but the expanded role of the Ottoman state in law was palpable. Scholars and jurists without official sanction were left on the margins, both supplementing and competing

$5^{8}$ On one of the few rhetoric manuals in Turkish, see Gürbüzel, "Teachers of the Public," 202-209.

59 Tijana Krstić, 'YYou Must Know Your Faith in Detail:' On the Redefinition of the Role of Knowledge and Boundaries of Belief in Ottoman Catechisms ('ilm-i hă âls)," in Historicizing Sunni Islam in the Ottoman Empire, c. 1450 - 1750 (Leiden: Brill, 2020).

6o Burak, The Second Formation of Islamic Law; On this literature, see Krstić, "State and Religion," 77-78; Of course, the increased role of government did not mean that the jurists simply mirrored the government's positions, as Atçil reminds us. Abdurrahman Atçll, "The Safavid Threat and Juristic Authority in the Ottoman Empire during the 16th Century," International Journal of Middle East Studies 49, no. 2 (May 2017): 295-314.

61 Samy Ayoub, “'The Sulțān Says:' State Authority in the Late Ḥanafî Tradition," Islamic Law and Society 23:3 (2016): 239-78. 
with the official state legal positions. Over the course of the seventeenth century, a vibrant and varied world of popular muftis emerged, operating with only partial regard to their imperial betters, and, on occasion, the state was forced to address them. At one end of the spectrum were learned legal scholars in Arab cities like Khayr al-Dīn al-Ramlī (d. 1671) and 'Abd al-Ghanī al-Nābulusî (d. 1731), who issued fatwas for followers across the empire without the official sanction of the government. At the other end, was a variety of semi-educated and largely anonymous authors who issued their legal opinions across Anatolia and the Balkans. On certain occasions, this popular legal world could seize control of a debate. For example, at the same time that Minkārizzāde was writing his pamphlets on millet-i Ibrāhìm, Abu'l-Wafā al-'Urḍī (d. 166o), the Shāfi'i mufti of Aleppo, complained about these popular elements in the debate over the permissibility of smoking tobacco:

When the Sultan permitted smoking in 1060 [1650]... no one with imperial authority in jurisprudence (idhna malakiyya fi'l-furū' wa'l-ușül) would say that smoking, which is widespread in our times, is forbidden, but neither would they deem it permissible. [This situation] energized a group to declare it forbidden, out of ignorance and stubbornness, and their talk has produced nothing except acrimony and quarreling. ${ }^{62}$

According to 'Urḍī, the government's legal system had created a thorny dilemma for itself. State jurists, i.e. those "with imperial authority in jurisprudence," were expected to rule on the permissibility of tobacco, but the sultan's decree prevented them from doing so, and in the ensuing vacuum, a populist or vernacular legal world stepped in to issue its own legal opinions.

The debate over millet-i Ibrāhim followed a trajectory similar to that of tobacco. As mentioned, the government had attempted to ban Muslims from declaring themselves "part of the religion of Abraham," but it is telling that so far we have little evidence of this earlier attempt. The lack of evidence might be a sign that the government failed to enact its legal position or to truly engage with the ümmis. Minḳārīzāde, who was not yet a şeyhülislām, may have seen the lack of action by the government as an opportunity to direct the conversation through the vernacular legal sphere-first in a pamphlet of fifteen folios and, when that failed, in a shorter, more digestible version. In the end, he was successful. His abridged work, whether in Kātib Çelebi's collection or

62 Abu'l-Wafā b. 'Umar al-'Urọī, Risāla fì hukm isti'māl al-dukhān, Library of Congress, MS Mansuri 4.79o, f. $1 \mathrm{a}$ 
in its own pamphlet form, was immensely popular, reproduced in pamphlets, miscellanies, margins, and notebooks hundreds of times over until it reached readers from the streets to the palace. ${ }^{63}$

Most formally trained scholars, however, did not regard Minkāāizāde's efforts in a positive light and, like al-Urdī, took a disparaging view of the vernacular legal world. Kātib Çelebi advocated that people should be allowed to say, "I belong to the religion of Abraham," given that if one tried to the change their opinion, "No one would pay any attention anyway; it would irritate the people and provoke them to contention, to no purpose." ${ }^{64}$ As demonstrated throughout The Balance of Truth, Kātib Çelebi felt that these debates would not have occurred if the common people-whom he sometimes called "ämme" and occasionally "cumhür," that is, the "masses" or the "public"—had not stuck their noses into the fray in the first place. ${ }^{65}$ So while Kătib Çelebi's laissez-faire recommendation to give the common people the freedom to say what they wish might seem gracious and tolerant to the modern reader, it also smacks of elitist condescension, a rejection of their presence at the table. Not surprisingly, the writings of these "popular" proponents and opponents of millet-i Ibrähim have not survived, and, if they have, are often anonymously or pseudonymously written. They lacked the authority, and therefore the authorship, to ensure that their writings would spread across the empire and be preserved for posterity. Instead, we access them through the comments of their detractors, like Kātib Çelebi, and through works specifically crafted for them, like Minḳārīzāde’s pamphlet.

63 For the palace copy, see UCLA Young Research Library Special Collections, Collection 896, Box 109, MS 740. The manuscript was copied in the hāne-i seferli, a building originally built in the early seventeenth century to prepare for military campaigns. By the end of the century, however, it had become a book production center. Unlike other examples, this pamphlet is written in perfect Ottoman naskh calligraphy and is heavily illuminated, though it is not the most accurate copy in relation to the original.

64 Translation adapted from Kâtib Chelebi, The Balance of Truth, 121; Kātib Çelebi, Mīzānü'lhakk fi ihtiyāril'-ahakk, 114-15.

65 While translating cumhür as "public" might seem like an anachronism, by the seventeenth century, the meaning of the word had started to shift from "the masses," to "republic" or some representation of popular will. See Marinos Sariyannis, "Ottoman Ideas on Monarchy before the Tanzimat Reforms: Toward a Conceptual History of Ottoman Political Notions," Turcica 47 (2016): 33-72; Wael Abu-'Uksa, "The Construction of the Concepts 'Democracy' and 'Republic' in Arabic in the Eastern and Southern Mediterranean, 1798-1878," Journal of the History of Ideas 80:2 (2019): 249-70; For Kātib Çelebi's use of cumhūr see Kātib Çelebi,

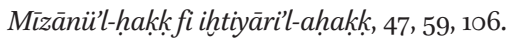


Minḳārīzāde's main aim was to convince Muslims who had become accustomed to asserting their identity by declaring they "belonged to the religion of Abraham" to abandon the practice. It was a fight over an everyday practice, but to make his case he turned toward theology. The problem, however, was that the Qur'an repeatedly tells Muslims to follow "millat Ibrāhìm," and never once uses the phrase millat Muhammad or millat al-Islām. Minḳārīzāde knew that the educated (havāṣs) understood these Quranic quotations as signifying that while Islam has Abrahamic antecedents, its law (şerîat) and religion (millet) are wholly its own, i.e that millet-i Ibrāhìm is Islam. However, he believed that ordinary people tend to be literalists (zähirbin) who interpret everything superficially and subvert the very purpose of the catechisms. For this reason, he set out to ban usage of the phrase "I belong to the religion of Abraham" in its literal, superficial meaning, that is, to stop people from stating that they were part of a separate religion of Abraham. To make his argument stick he had to, one, expand the meaning of the word millet, and, two, make sure that his argument would be adopted by more than a few legal scholars.

Minkārīzāde opens his pamphlet with the contention that "to practice ('amel) [the religion] in accordance with the law (şerî'at) and religion (millet) of a preceding prophet means to follow our Prophet's law and religion. It does not mean to follow the law and religion of that preceding prophet." 66 To clarify his words, he makes an analogy to inheritance: once a piece of property is bequeathed to an heir, it loses all connection with the original owner. Islam bears a similar relation to the Prophet Abraham. Once Muhammad emerges as a prophet of God, he inherits the religion, that is, the millet, from Abraham. ${ }^{67}$ This initial argument leads him to his main contention that the phrase is not permissible "because the literal meaning of saying 'I belong to the religion of Abraham' indicates that the religion is still that of the Prophet Abraham and that the practice [of the religion] should occur according to that of the Prophet Abraham." ${ }^{28}$ If this were true, "then the Prophet Muhammad would not be God's messenger, he would be an earlier prophet's messenger and [the Prophet Muhammad] would have to be an intermediary between Abraham and his

66 Minḳāīzāde Yahyā Efendi, Risāle-i millet-i Ibrāhīm, Beyazıt Devlet Kütüphanesi, Veliyüddin MS 1064, f. 166b. All references below to the text refer to this manuscript.

67 Minḳārīzāde bases this initial argument on some key works of Hanafi ușūl al-dīn, mostly by earlier commentators of classical Hanafi works, like Faḩr al-Islām al-Pazdawī (d. 1100) and Akmal al-Dīn al-Bābartī (d. 1384/5)

68 Risāle-i millet-i Ibrāhōm, f. 167 a. 
community." ${ }^{99}$ In other words, the Prophet Muhammad would be a messenger of Abraham, not of God.

Minkārizzāde then responds to potential objections, the main one being that it is permissible to say "I belong to the religion of Abraham" because millet pertains only to the principles of religion (ușül-i din) and on these all the prophets of God are in agreement. ${ }^{70} U s \underline{u} l-i$ din here means those things that must be believed, in other words, dogma or creed: the unity of God, prophethood, the day of judgment, and so on. ${ }^{71}$ Since all of God's prophets concurred on these basic beliefs, declaring that one belongs to Abraham's religion could have no negative connotations. Minkāāizāde, though, argues that millet applies not only to the foundational principles of religion but also to furüc, the "branches" of practice and jurisprudence, such as prayer, fasting, alms-giving, pilgrimage, and jihad. ${ }^{72}$ In other words, to say that one belongs to Abraham's religion is to reject the sharia and Islam. This is why Minkāāizāde repeatedly suggests that saying one belongs to a previous prophet's millet means following that prophet's sharia as well. ${ }^{73}$ Only by interpreting millet as encompassing law and jurisprudence can Minkāāizāde provide an argument for banning the declaration, "I belong to the religion of Abraham."

To make this argument, Minkāin̄zāde must support a larger claim about the relationship between belief and practice in religion by equating the concepts of millet, dìn, and şeríat. As Jacob Olidort notes in his study of early Muslim exegetes' understanding of milla, the word reveals a "tension... [as to] how to define the relationship between beliefs and the practices that signify allegiance to them." ${ }^{74}$ His observation applies also to the Ottoman-era debate on the subject. Earlier commentators cited by Minkāāīzāde, such as Birgīīi Meḥmed (d. 1573) and al-Bayḍawī, generally agree that din and millet are synonyms and connected to matters of belief $\left(i^{i} t i k \bar{a} d\right) .{ }^{75}$ Minkāāizāde, however, argues that millet goes beyond belief and incorporates the sharia, that is, the daily practices

69 Risāle-i millet-i Ibrāhīm, f. $167 \mathrm{a}$.

70 Risāle-i millet-i Ibrähìm, f. $167 \mathrm{~b}$.

71 As Gimaret notes, ușūl al-dìn is essentially a synonym of 'ilm al-kalām. See $E I^{2}$, s.v. Ușūl al-Dīn (Gimaret).

72 It is unclear exactly what Minḳārīzāde is referring to when he says "furūe." Is it furū $i-i$ dìn or furü $\bar{u}^{c} i f i k h$ ? In either case, the intended meaning is the practice of Islam according to its legal prescriptions.

73 Risāle-i millet-i Ibrāhìm, f. $167 \mathrm{a}$.

74 Olidort, "Portraying Early Islam as the milla of Abraham," 318.

75 "...In the Figh akbar 'religion (din) is a noun that relates to (wāqi ' 'alā) faith ( $\bar{\imath} m \bar{a} n)$ and Islam and all the commandments of the law (şeray $\left.\bar{\imath}^{\prime}\right)$." Translation taken from Nuruosmaniye Library, MS 4952, f. 47b. See also, Kâtib Chelebi, The Balance of Truth, 115-16. The same statement is made in Kara, Mızraklı Ilmihal, 73. Anonymous, Ilm-i hăl, Bibliotheque Nationale de Tunis, MS 2520, p. 2; Classical lexicographers had differing opinions on the 
that constitute Islam. Claiming a different millet, like that of Abraham, means advocating for a different sharia, which implies a disregard for the Islamic ritual obligations and an alternative way of being Muslim. ${ }^{76}$ Professing to be a part of the millet-i Ibrähim, a central element of faith a century earlier, had suddenly become unacceptable. By reinterpreting the meaning of millet, Minkārīzade proposes a different vision of religion, and his critics highlight this particular claim as indefensible and incorrect.

Minkāāizāde's other writings suggest that his reinterpretation of millet was part of a larger project of redefining the standards of Muslim belief. When he became şeyhülislām in 1662, he advocated for a more expansive definition of heresy. In a written debate with Khayr al-Dīn al-Ramlī, an influential but independent scholar in Palestine, he put forward his case. His argument mirrors the overall point of his treatise on millet-i Ibrähim — everyday actions and words can mark one as an apostate or infidel, contrary to the established tradition that one must make an explicit and intentional declaration of apostasy. ${ }^{77}$ Al-Ramlī responds that it is "prohibited to anathematize (takfir) a Muslim for a rarely said word or even a single word."78 "Millet-i Ibrähïm" was one such word that that now arose suspicions of heresy.

What did the proponents of millet-i Ibrāhìm make of Minḳārīzāde's arguments? The few responses that survive all reject his attempt to tighten the

meaning of the word milla. One late thirteenth-century Maghrebi lexicographer, Ibn Manzūur (d. 1311), defines milla as sharia and dīn. Olidort, "Portraying Early Islam as the milla of Abraham," 317.

76 While there is no evidence that anyone attempted to formulate a separate sharia for the millet-i Ibrähim, some scholars did address the question of whether there could be alternative sharias. A scholar named Muhammad b. Abi Bakr al-Hịșārī wrote a treatise in response to a patron who read the famous prayer manual Daläil al-khayrat and wondered whether the Qur'an attests to the existence of other sharias, specifically those of millat Ibrāhìm. Dalāil al-khayrat does not seem to make any mention of millat Ibrāhīm, however, and al-Hịșārìs pamphlet appears to have been written without reference or relation to Minḳārīzāde's work. Milli Kütüphane, MS A938, ff. 84a-85b.

77 On this expanded notion of heresy, see Krstić, "State and Religion," 83; Ramlì's response echoes his words in his other works. See Guy Burak, "Faith, Law and Empire in the Ottoman 'age of Confessionalization' (Fifteenth - Seventeenth Centuries): The Case of 'Renewal of Faith," Mediterranean Historical Review 28:1 (2013): 7-8, 11-13.

78 Ramlī, Untitled Treatise on Heresy, Hekimoğlu MS 322, f. 303a; Reşid Efendi MS 1215, f. 192ab.

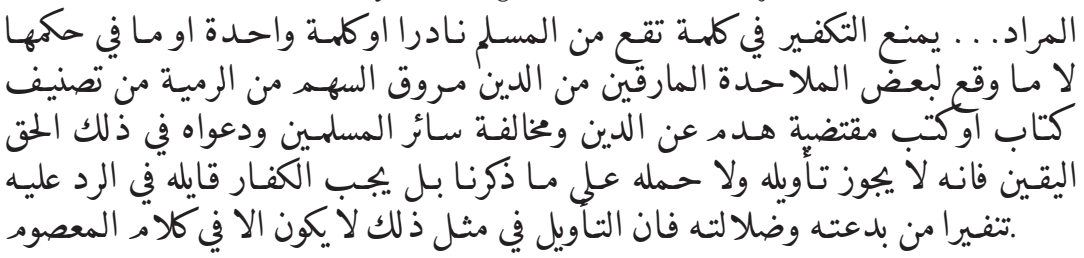


circle of Islam. Most of these responses took the form of short and simple rejoinders by unknown or anonymized figures, e.g. a certain Ḥasan Efendi, or Izmīrī Hậaz Efendi or 'Ismāîl Efendi, one of the ulema of Bursa. Their responses seem to have been written after Minkāāizāde had become şeyhülislām in 1662 and was in a stronger position to impose his views and punish dissenters. These responses first and foremost oppose expanding the notion of millet beyond the fundamental beliefs of religion. Quoting the Central Asian scholar Ḥusāmeddīn Ahsiketī (d. 1247), these anonymized writers insist that millet means dìn, and not şeri'at. ${ }^{79}$ A certain Ḥasan Efendi states that "the term millet is mostly used in principles of faith. It is not used in practical law $\left(f u r \bar{u}^{\prime} d a\right)$ and it does not have the meaning of sharia." ${ }^{80}$ The critics of Minkārīzāde state that anyone who declares that he belongs to the religion of Abraham is actually saying that he belongs to the religion of Muhammad. All the prophets belong to the same millet and by saying they are part of Abraham's millet, they are only demonstrating their appreciation of Abraham. ${ }^{81}$ One commentator says that the Quranic command to "say [I belong to] the religion of Abraham" was a way for the nascent Muslim community to appeal to Jews and Christians by respecting their forefathers, whereas others say it was a rebuke of these groups. ${ }^{82}$ In the longest and most critical response, an anonymous shaykh dismisses as ludicrous Minkārīzāde's claim that those who declare they belong to Abraham's religion actually believe that Islam is literally Abraham's religion or that Abraham is somehow superior to the Prophet Muhammad. ${ }^{83} \mathrm{~A}$ respondent with less civility, identified only as Ni'matullah, cuts to the chase: who is Minkāainzāde to declare those who say they are part of Abraham's religion to be heretics? ${ }^{84}$ The tone may be harsh, but the debate went to the core of what it meant to be a Muslim.

79 Beyazit Devlet Kütüphanesi, Veliyüddin MS 1064, ff. 169a, 17oa; Manisa Yazma Eserler Kütüphanesi MS 4478 ff. 18oa, 182b. On Ahsiketī see Mehmet Boynukalın, "Hanefî Usûl Muhtasarlarının Gelişimi: (II) Hüsameddin El-Ahsîketî’nin El-Müntehab’ı ve Hanefî Usûlündeki Yeri," Kocaeli Ilahiyat Dergisi 1, no. 2 (Aralık 2017): 21-42.

8 o Beyazıt Devlet Kütüphanesi, Veliyüddin MS 1064, ff. 168b; Manisa Yazma Eserler Kütüphanesi MS 4478 ff. 18oa. The eighteenth-century Indian scholar al-Ṭahānawī (fl. 1745) seems to echo some of the critiques of these seventeenth-century scholars, insisting that milla refers only to the fundamentals $(u s ̦ \bar{u} l)$ of a legal system, not the positive laws $(f u r \bar{u})$. Olidort, "Portraying Early Islam as the milla of Abraham," 317-18.

81 Beyazıt Devlet Kütüphanesi, Veliyüddin MS 1064, ff. 168b; Manisa Yazma Eserler Kütüphanesi MS 4478 ff. 18oa.

82 Beyazit Devlet Kütüphanesi, Veliyüddin MS 1064, ff. 169ab, 17ob; Manisa Yazma Eserler Kütüphanesi MS 4478 ff. 18oab, 181b, 183ab.

83 Beyazit Devlet Kütüphanesi, Veliyüddin MS 1064, ff. 17ob; Manisa Yazma Eserler Kütüphanesi MS 4478 ff. 184a.

84 Text: “kayfa yukfir mu'taqidahu," Süleymaniye Kütüphanesi, Aşir Efendi MS 427 f. 49b. 
Lay people ('avāmm) in the Ottoman period were expected to recite the basic precepts of the faith and follow its core practices. When the influential şeyhülistām Ebü's-su'ūd Efendi (1490-1574) reportedly was asked what the din and millet of Islam are, he responded that it is sufficient for ordinary people to believe in the unity of God, the prophethood of Muhammad, and the validity of the sharia. However, "it is not necessary for them to have a close grasp of the concepts or details of legal rulings." ${ }^{85}$ Yet, as a consequence of the confession-building policies of the Ottoman Empire in the sixteenth century, ordinary Muslims were increasingly taking part in larger legal and theological discussions. ${ }^{86}$ Kātib Çelebi saw this intrusion of commoners into public discussions as the very cause of the polemics of the period and his solution was to chide them for participating and to dismiss their words. He goes so far as to distort Minḳārīzāde's treatise by inserting his own comments against commoners into his summary of it. ${ }^{87}$ This is all to be expected and reflects the traditional hierarchy of revelation, in which only the more educated elite (havāṣs ) are free to explore multiple notions of being Muslim. ${ }^{88}$ For Minḳārīzāde, however, addressing an audience of ordinary Muslims - those readers who tired

85 Mehmet Ertuğrul Düzdağ, ed., Şeyhülislâm Ebussuud Efendi Fetvaları Işı̆̆ında 16. Asır Türk Hayatı (Istanbul: Enderun Kitapevi, 1972), 176; this fatwa is not included in the critical edition of Ebü's-su'ūd's fatwas and was probably a later addition. Ebussuûd, Ma'rûzât, ed. Pehlul Düzenli (Istanbul: Klasik, 2013); however, the same expression appears in Kara, Mızraklı İmihal, 73 .

86 The participation of ordinary Muslims in these discussions is most clearly demonstrated in Terzioğlu, "Ilm-i Hal;" Krstić, "From shahāda to 'aqïda;" on the push for ordinary believers to be well-versed in the details of Islam in the Ottoman period, see Krstić, "You Must Know Your Faith in Detail."

87 For example, although Kātib Çelebi usually faithfully copied Minḳārīzāde’s pamphlet, he inserted the phrase "Nevertheless this is not the way ordinary people (cumhūr) see it" following Minkāāizāde's description of Birgivì's position on the difference between millet, dìn, and sharīà. Kâtib Chelebi, The Balance of Truth, 116; Kātib Çelebi, Mīzānül-ḥaḳ fi ihtiyāri'l-ahakḳ, 106. For Minḳārīzāde's statement, see the extended treatise in Nuruosmaniye Kütüphanesi MS 4952 f. 46 b.

88 Havāsș is a flexible social category referring to the elite. Traditionally a political distinction, the havāș consisted of the ruler and those around him, the ruling elite, whereas the 'avāmm comprised the rest, that is, those who paid taxes. At the same time, havāss and 'avāmm also functioned as categories of moral and intellectual distinction, broadly overlapping with their respective political counterparts. One of the normative values separating the havāṣs from the 'avāmm was education. What non-elites or the 'avāmm lacked was not education per se, but the very capacity to be educated. For this reason, I refer to havāsș as "the educated elite" in this article. On the topic, see Ahmed, What Is Islam?, 368-77. See also my forthcoming monograph, Pamphleteering Islam. 
easily - and involving them in (some of) the details of his argument was the key to successfully propagating his particular understanding of millet.

At first sight, it seems that Minkāāizāde, due to an internal contradiction in his argument, is interested in upholding the distinction between ordinary people and the educated elite in his treatise. As mentioned, Minkāinzāande argues that the literal or zāhiri meaning of the phrase "I belong to Abraham's religion" is that Islam is not the religion of the Prophet Muhammad but of Abraham, and therefore it is not permissible to utter it. However, the Qur'an specifically tells Muslims to declare that they are part of millat Ibrāhim (but never mentions millat Muhammad or millat al-Islām), and, thanks to the catechisms of the sixteenth century, many Ottoman Muslims did so. Moreover, in one hadith, the prophet Muhammad awakens one morning and says, "We arise into the state of Islam (aṣbahnna 'alä fitrat Isläm)... and into the dìn of our Prophet Muhammad and the milla of our forefather Abraham..." ${ }^{89}$ To resolve this contradiction, Minkārīzāde divides his response into one set of instructions for the educated elite and another for ordinary people. The educated elite understand that the phrase was not meant to be taken literally and can therefore say it. Ordinary people, however, were literalists (zähirbin), who, if they overheard the educated elite saying the phrase, would misinterpret it and utter it without the proper belief. He therefore argues that the educated elite should only say the phrase privately, in the company of other educated people, and not where it may be overheard and misinterpreted..$^{90}$ Moreover, when saying it, the educated elite were to add the proviso (karine) that the religion, i.e. Islam, was originally the prophet Abraham's and became the Prophet Muhammad's upon his revelation. In other words, millet-i Ibrāhim is the religion of Muhammad..$^{91}$ Not adding this proviso indicates that the speaker believes in the phrase's literal and superficial (zähirī) meaning, i.e. that he or she does not believe in Islam.

No one, perhaps not even Minkāinīzāde himself, was convinced by his proposed solution. An anonymous critic of Minkārīzāde lambasts him for his seeming hypocrisy: Minḳārīzāde first states that it is not permissible to say "I belong to the religion of Abraham" and then reverses course. Which one is it, the critic wonders? ${ }^{92}$ Kătib Çelebi thought it was cruel to tell ordinary people, who slavishly obey custom, that they are not allowed to say

89 Risāle-i millet-i Ibrāhīm, f. 168a.

go Risāle-i millet-i Ibrāhīm, f. 168 a.

91 Risāle-i millet-i Ibrāhìm, f. 168a.

92 Anonymous response to Minkāāizāde’s pamphlet, Beyazıt Devlet Kütüphanesi, Veliyüddin MS 1064, f. 171a; Manisa Yazma Eserler Kütüphanesi MS 4478 f. 184b. 
the phrase while telling the educated elite that it is permitted. "It would mean imposition of hardship to declare 'No, these words are wrong. The educated elite, who know their origin, may use them, but the common people must not.' No one would pay any attention anyway; [banning the phrase] would mean irritating the people and provoking them to contention, to no purpose."93 Even Minkārīzāde finds his required proviso, which is intended to explain and elucidate the phrase's non-literal meaning, pointless because not everyone is able to tell if the speaker uttering it did so with or without belief in its literal meaning. The ambivalence toward his own solution derives from his determination that "in sum, every word is understood according to its literal meaning (hâasıl-ı kelām her söz zāhirine $m \bar{a} h m m \bar{u}(d \iota r) .{ }^{\prime 94}$ In other words, everything will eventually be reduced to its literal, base meaning, especially in a world in which it is nearly impossible to separate the educated elite from ordinary people. Given that "it is not permissible for us to say any word whose literal meaning we are not allowed to believe," it is best to stop uttering the statement entirely, he argued. ${ }^{95}$ In some ways, Minkārīzāde is implicitly calling for the elimination of different expectations for ordinary people and educated elites and judging everyone by the same standard of behavior.

Despite the fact that Minkārinzāde suggests that the educated elite could say the phrase while the ordinary people were to abstain, it seems that his intention was to stop usage of the phrase entirely. Indeed, Minkāāizāde was not trying to lecture the educated elite: he specifically wrote the pamphlet for a reader who had difficulty reading. Educated scholars like Kātib Çelebi already knew the phrase's non-literal interpretation and did not need Minkārīzāde to elucidate it for them. For this reason, Minḳārīzāde sought to incite to action a different group of readers, those who possessed some capacity to read his pamphlet but did not consider themselves part of the educated elite and who would conclude that uttering "I belong to the religion of Abraham" was unacceptable.

Why does Minkāinzāde address the vernacular legal world to make this argument? To answer this question, it would be necessary to undertake a comprehensive study of his work before and after he became şeyhülisläm. To date, no such study exists. However, another one of Minkārīzāde's writings sheds light on his interest in addressing the public. As he was writing his pamphlets on millet-i Ibrähim, he also issued a fatwa calling for the execution of a scholar

93 Adapted from the translation of Kâtib Chelebi, The Balance of Truth, 121; Kātib Çelebi, Mìzānül-hakk fi ihtìāril'-ahakk, 114-15.

94 Risāle-i millet-i Ibrāhīm, f. 168b.

95 Risāle-i millet-i Ibrāhīm, f. 168b. 
known as Kürd Molla on charges of heresy. ${ }^{96}$ Kürd Molla had written a commentary critical of the aforementioned Birgivī Mehmed's al-Tarīqa al-Muhammadiyya, and while many others had criticized Birgivī without being punished, two points sealed Kürd Molla's fate, in Minḳārīzāde's view. Among the various heresies propagated by Kürd Molla, the most serious was that he openly claimed that exotericists (ahl al-zähir) look at the externality of actions - that is, whether an act conforms to the law-whereas esotericists (ahl al-bäțin) look at the internality of actions - that is, the intention behind the act - and each approach to Islam is acceptable and can coexist. ${ }^{97}$ Echoing the aforementioned view that practice and belief are intimately related, Minkārīzāde finds Kürd Molla's views unacceptable. Minkāāizāde's recommendation that Kürd Molla be put to death, without the possibility of repentance, however, stems not from Kürd Molla's theological views, but from the fact that he had spent years "liberally lecturing and composing books... with the sole purpose of arousing within the weak and feeble the delusion of these misguided errors. ${ }^{\prime 98}$ Minkārīzāde's call for Kürd Molla's execution demonstrates the importance he attached to addressing ordinary people. Kürd Molla was a rival not only in terms of approaches to Islam but also in his ability to reach the public, and therefore he needed to be silenced.

\section{Vernacular Receptions}

To this point, I have dealt with the vernacular legal world only indirectly. As few statements by vernacular legal writers are extant, I have been forced to reconstruct their views from the words of elite scholars who cultivated or criticized them. Yet, the vernacular legal world did not just passively receive ideas but rather transformed them, turning Minkārīzāde's arguments into an active call to declare as heretics any partisans of Abraham's religion.

In the eyes of his critics, Minkāinizāde's attempt to reach the vernacular legal world had been too successful. One man, the aforementioned Ni'matullah, wrote in mediocre Arabic (he was most likely a semi-educated ümmi; much of Kātib Çelebi's earlier critique of the anonymous shaykh could apply to

96 The story of Kürd Molla and Tatar Imām is one of the more famous examples of Kaadẹizādeli fanatacism that Zilfi highlights from the chronicle of Naima. Zilfi, The Politics of Piety, 14546; Naima Mustafa Efendi, Târih-i Naî̀nâ (Ravzatüll-Hüseyn fî Hulâsati Ahbâri'l-Hâfikayn), ed. Mehmet İpşirli, 4 vols. (Ankara: Türk Tarih Kurumu Yayınları, 2007), 1434-36.

97 "A copy .... decrying ... Muhamammad al-Kurdī," Köprülü Library, Ahmedpasa MS 152, ff. 78a.

98 "A copy .... decrying ... Muhammad al-Kurdī," Köprülü Library, Ahmedpasa MS 152, ff. 77a-79a. 
Ni'matullah's writings) that there had appeared a "great plague $(\bar{a} f a)$ " in "this Sunni community (sunna) of ours," a sanctimonious group of people who were unhappy at the respect ordinary people showed to the holy forefathers (salaf). A thinly veiled description of Minkārīzāde follows:

They told the converts (muhtadin) and confused the common people to reject the millat Ibrähim in opposition to the Qur'an and the Sunna. They went astray and led others astray. Among them was a man who composed two pamphlets [i.e. Minḳārīzāde], one small and one big, though his small one was big in terms of inciting the common people against the educated elite and the holy forefathers from the time of the Prophet Muhammad until today. They declared as a heretic anyone who said, "we belong to the religion of Abraham," regardless of who he was. ${ }^{99}$

Ni'matullah's words convey the intense emotions that the debate over millet-i Ibrähim elicited among Muslims at the time. Ni'matullah sees the rejection of the phrase "millet-i Ibrähim" as an attack on the very tradition (sunna) of Islam itself and upon its holy forefathers, the salaf. ${ }^{100}$ He recounts how these new partisans of the faith repeated many of Minkāinzāde's arguments, such as the comparison between prophecy and inheritance or that the phrase "I belong to the religion of Abraham" implies that Muhammad is the prophet of Abraham and not of God. Most importantly, his comments show that these partisans expanded Minkāāizāde's argument against using millet-i Ibrāhìm to make the phrase a clear marker of heresy. Minkārīzāde never explicitly stated that saying, "I belong to the religion of Abraham" was a sign of heresy, but the reception of Minkārizande's pamphlet in the legal vernacular world made it so. What Ni'matullah describes is not the learned debates of jurists over subtle distinctions between types of heresy, but a popular form of public politics.

Ni'matullah's comments also demonstrate how successful Minkāīīzāde was in reaching a new group of readers with his second pamphlet. Ni'matullah mentions that recent converts (muhtadīn) and ordinary people ('awämm) have been carried away by Minkārīzāde's words to attack the educated elite (khawāșș). Ni'matullah complains that the ordinary people "consult their

99 Ni`matullah's response, Süleymaniye Library, Esad Efendi MS 356o, ff. 88b-89a; Asir Efendi MS 427 ff. $49 \mathrm{ab}$.

100 Ni'matullah's response, Süleymaniye Library, Esad Efendi MS 356o, ff. 88b-89a; Asir Efendi MS 427 ff. 49a. 
pamphlet at their convenience to embellish their speech with lies and fill it with irrelevant proofs... and the outcome of their pamphlet is a tripling of the words of one of them, [words] that say that to enter Abraham's religion is to exit Muhammad's religion and become an infidel."101 Kātib Çelebi would have been horrified, his fears of public disorder due to popular participation had been realized. Minkāāizāde, on the other hand, likely would have been happy that he could rally people to his cause.

Ni'matullah's words also demonstrate the speed with which the topic of millet-i Ibrähim had entered the realm of polemics. As proof of this, one reader of Ni'matullah's short response found his views idiotic and jotted down in the margins a number of long rejoinders in which he accuses Ni'matullah of slander, being childish, and arguing incomprehensibly. ${ }^{102}$ The longest of this reader's comments, however, is in response to Ni'matullah's allusions to Minkāāizāde. Among a variety of insults, he writes, "How many faults and excesses are in his [Ni'matullah's] writings. Only beasts and animals make sounds like these, and you would waste your time trying to correct them." As the commentator continues to cast aspersions, he remarks that,

it is no wonder that he [Ni'matullah] is one of the Sufis of our time who has ruined the beliefs of the faithful, especially in Constantinople, so that they stubbornly resist these matters of religion and yet, nonetheless, they claim to be saints, as if they've lost all reason and thought! I wish I knew what was the point of all this depravity?103

This reader's reference to Sufis is intriguing. The issue of millet-i Ibrähim, of course, had little to do with Sufism, at least not directly. However, Minkārīzāde's comments represented a step in a new direction regarding the relationship between sharia and Islam, a direction that was less favorable to forms of Islam, such as Sufism, that drew legitimacy and inspiration from sources beyond the sharia. Not surprisingly, whether Minkāainzāde intended to or not, his pamphlet had transformed the question of millet-i Ibrähim from a minor theological issue into a litmus test of one's positions in broader societal conflicts.

101 Ni'matullah's response, Süleymaniye Library, Esad Efendi MS 356o, ff. 89a; Asir Efendi MS

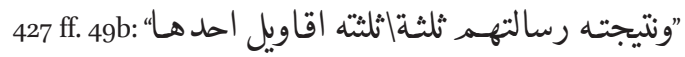

102 Süleymaniye Kütüphanesi, Esad Efendi MS 356o, f. 88b-89a (margins).

103 Süleymaniye Kütüphanesi, Esad Efendi MS 356o, f. 89a (margins). 
In the 1720s, a fatwa on the question of millet-i Ibrāhim was made the very first entry in şeyhülislām Yenişehirli 'Abdullah Efendi's (d. 1743) compilation of legal rulings. The fatwa decreed that when Muslims are asked, "what is your religion (millet)?" they are to answer "I belong to the religion of Muhammad," not "I belong to the religion of Abraham."104 It had been over seven decades since Minkāāīāde had written his two pamphlets and his view that Muslims should not say that they belong to Abraham's religion had become part of an imperial collection of legal rulings. Now, Muhammad too, not just Abraham, had a millet and this was the proper millet for Muslims. The fatwa also indicates that many Ottoman Muslims continued to declare that they belonged to Abraham's religion. The debate was still current and judging by the copy dates of Minkārīzāde's treatise, it would remain relevant for another century.

The fight over millet-i Ibrāhìm demonstrates how a declaration of faith could become a sign of heresy in little over a century. As is hopefully clear by now, the debate was never about the status of the other Abrahamic religions, that is, Judaism and Christianity, in the Middle East. It was instead a fight over the practices that defined Islamic belief in the Ottoman Empire. At first, encouraging Ottoman Muslims - many of whom were recent converts or subscribed to forms of Islam that sought authority from beyond the sharia - to declare they belonged to Abraham's religion served as a means to reinforce a notion of Islam based on the sharia. In the seventeenth century, however, when the confessional identity of the empire as a Sunni Muslim polity was more secure, the phrase became a victim of its own success and was targeted by a movement to constrict the definition of Islamic religiosity even further. Minḳārīzāde Yahyāā, a future şeyhülislām, argued that saying "I belong to Abraham's religion" entails a rejection of Muhammad's prophethood and, more importantly, the sharia. To make this argument, Minḳārīzāde

104 The fatwa in question is listed under a special rubric regarding belief. The collection and arrangement of fatwas in imperial collections was done by the clerks of the office of the şeyhülislām, so it is difficult to ascribe the choice solely to the şeyhülislām himself. "Question: When Zeyd the Muslim is asked, 'What religion [millet] are you?' which of the following must he say: 'I belong to the religion of Muhammad...' or 'I belong to the religion of Abraham...?' Answer: He must say, 'I belong to the religion of Muhammad." Yenişehirli 'Abdullah Efendi, Behcetü'l-Fetâvâ, ed. Süleyman Kaya et al. (Istanbul: Klasik, 2011), 25. 
expanded the definition of the word millet to include both the foundations of basic belief and daily religious practice according to the law.

More significantly, the debate over millet-i Ibrāhim sheds light on the workings of vernacular legalism in the Ottoman Empire. I have adumbrated the existence of a space of legal debate and discussion that resided below the formal world of jurists, judges, and professors. The semi-educated readers and writers who participated in vernacular legalism approached law in a simple fashion, focusing less on formal arguments and interpretations and more on using law as a space of public and polemical debate. Scholars today have generally overlooked legal vernacularism because its texts tend to be vulgar and its participants marginal. Often, we can only access the vernacular legal world through the words of its critics or those elite scholars that wished to make use of it. Minkāinizāde was one of the latter. He tried and succeeded in addressing this vernacular legal world. In his second pamphlet on millet-i Ibrähìm, he shortened his initial, little known pamphlet to two or three folios, and it was quickly copied and read across the empire. As his arguments circulated in the vernacular legal world, they were actively transformed. Minkāinzāde simply stated that it is not permissible for a Muslim to declare that he belongs to the religion of Abraham, yet readers of his pamphlet went further and declared that anyone who stated, "I belong to the religion of Abraham," was a heretic. In other words, the reception of his arguments in the vernacular legal world turned the issue into a stark marker of whether or not one was part of the Muslim community. The continued vigor of the debate over the course of the eighteenth century suggests that the vernacular legal world continued to thrive in the Ottoman Empire as a space for popular politics for decades to come.

\section{Acknowledgements}

I would like to thank the anonymous reviewers, Tijana Krstić, Aslıhan Gürbüzel, Robert Dankoff and the participants of the "Entangled Confessionalizations?" Conference in Budapest in 2018 for their comments on various versions of this article. I would also like to thank the editor of Islamic Law and Society, David S. Powers, for helping to refine the article's wording, style, and concepts. Research for this article has been funded by the European Research Council (ERC) under the European Union's Horizon 2020 research and innovation programme (grant agreement No 648498-OTTOCONFESSION). 


\section{Minkāāīzāde Yaḥyā Efendi's treatise on Millet-i Ibrāhìm - Transcription and Translation ${ }^{1}$}

\section{Critical Edition}

\section{Source Texts:}

A: Beyazıt Devlet Kutuphanesi, Veliyüddin MS 1064

B: $\quad$ UCLA Special Collections, Collection 896, Box 109 MS 749

C: $\quad$ Istanbul Üniversitesi Nadir Eserleri Kütüphanesi MS T5917

D: Harvard University, Houghton Library, MS Arab 292

A 166b / B 1b / C 1a / D 99a

Bismillāhi'r-raḥmāni'r-rahīm. El-ḥamdu lillāhi 'alā milleti'l-islām, milleti Muhammedin 'aleyhi'ṣ-ṣalātü ve's-selām. Emmā ba'd: $\mathrm{Bu}$ 'abd-i' faḳīr Minḳarīzāde aṣlaḥa'llāhu subḥānahu ve te‘ālā ${ }^{4}$ me‘ādehu ḥālā beyne'l-enām millat İbrāhīm 'aleyhi's-selām huṣūṣında dāir olan su'āl5 cevābında 'azīzü'lmenāl nīçe vecih taḳīr ve bir risāle-i bedī‘a taḥrīr èdüb, lākın keșīretü'ş-şi`ab olmag̉ile muṭālacasında te‘ab çekilmesin dèyü ihtișār olınub ḳadr-i hạācet\{e\} iḳtișār ${ }^{7}$ olındı.

Aṣhạa-i bāṣāire huafĩ ve erbāb-i żamāiire muhtefí ${ }^{8}$ olmaya ki kütüb-i uṣūlda karār vėrilen üzre mezheb ve ḳavl-i muhtār budur ki: Muḳaddem gelen nebīniñ şerīati ve milleti ile ‘amel bizim nebīmüziñ şerīati ve milleti olmak ${ }^{9}$ üzerinedir. Yohsa muḳaddem [C ib] gelen nebīniñ şerīatı ve millet olmak üzerine ${ }^{10}$ degildir. Aña bināen ki¹1 muḳaddem gelen nebīniñ şerīati ve milleti bizim nebīmize ‘alā

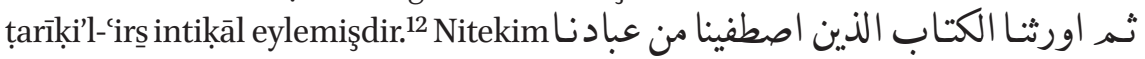
āyet-i kerīmesi delālet èder.

\footnotetext{
1 I would like to sincerely thank Robert Dankoff for helping me resolve a number of ambiguities in the text and refine the critical edition. All mistakes are my own.

2 Emmā ba'd: missing in B.

3 Missing in A.

4 subhāanahu ve teāāā: Missing in A.

5 A: su’ālın

6 B: bu; missing in D.

7 A: iḩtiṣār.

8 D: mahfì.

9 Missing in B.

10 B: üzredir.

11 Missing in AD.

12 B: ètmişdir.
} 


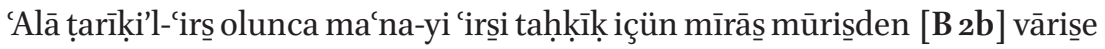
intikāa ètdikde vārise mużāf olub ve anuñ milki olub mūrise mużāf olmayub ve anuñ milki olmayub ${ }^{13}$ ve bi'l-cümle ba'de'l-intikāl vārișe mahșūṣ olub mūrisiñn 'alāḳası ḳalmaduğı gibi muḳaddemden bizim nebīmize şerīat ve millet dahi intikāl ètdikde böyledir.

Bu kelāmımız ${ }^{14}$ Keșfi Pezdevìden ve Takriờden ve Tavdīh'den me'hūz̄dır.

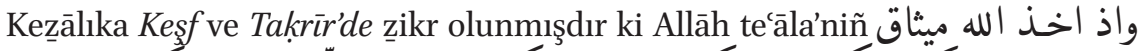

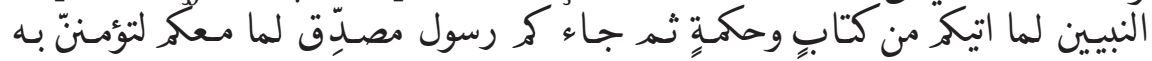
[C 2a] ḳavl-i şerīfinde [B 3a] nebiyyīn ${ }^{15}$ üzerine taṣdīḳe mis̄āḳ ${ }^{16}$ ahzz eylemesi enbiyā 'aleyhimü's-selāmiñ Ḥażret-i Muhammed 'aleyhi's-selām’a ittibāları vācib [A 167a] olmada Ḥażret-i Muhammed 'aleyhi's-selāmiñ ümmeti menzilesinde olmalarına delīldir. ${ }^{17}$

[D 99b] Böyle olunca muḳaddem gelen enbiyāniñ şerāyi ${ }^{18}$ ve mileli ile 'amel anlarıñ şerāyi ${ }^{19}$ ve mileli ${ }^{20}$ olmak üzerine olsa anlar Ḥażret-i ${ }^{21}$ Muḥammed 'aleyhi's-selām'a tābi'ler ve ümmeti ${ }^{22}$ menzilesinde iken Ḥażret-i Muḥammed 'aleyhi's-selām anlara ${ }^{23}$ tābi ve anlarıñ ümmeti menzilesinde ${ }^{24}$ olmak lāzim gelür. Ve Menār şerhịinde İmām Nesefĩ yazdığına göre 'amel muḳaddem gelen nebīniñ şeríati [ $[\mathbf{B} \mathbf{3} \mathbf{b}]$ ve milleti olmak üzerine olsa Ḥażret-i Muḥammed 'aleyhi's-selām Allāh te‘ālā’nıñ resūli olmayub mukaddem gelen nebīniñ resūli olub anuñ ile anuñ̃ ${ }^{25}$ ümmeti beyninde vāsița ${ }^{26}$ olmak lāzim gelür. ${ }^{27}$

[C-2b] İmdi hālā ${ }^{28}$ dā’ir' ${ }^{29}$ olan su'āl ki ${ }^{30}$ ümmet-i Muhammed 'aleyhi's-selām'dan bir kimesne millet-i İbrāhīm'denim dẻmek cāiz midir dèrler. Bu takrīrden anuñ cevābı ${ }^{31}$ ma lūm oldı ki cầiz degildir. Zīrā millet-i

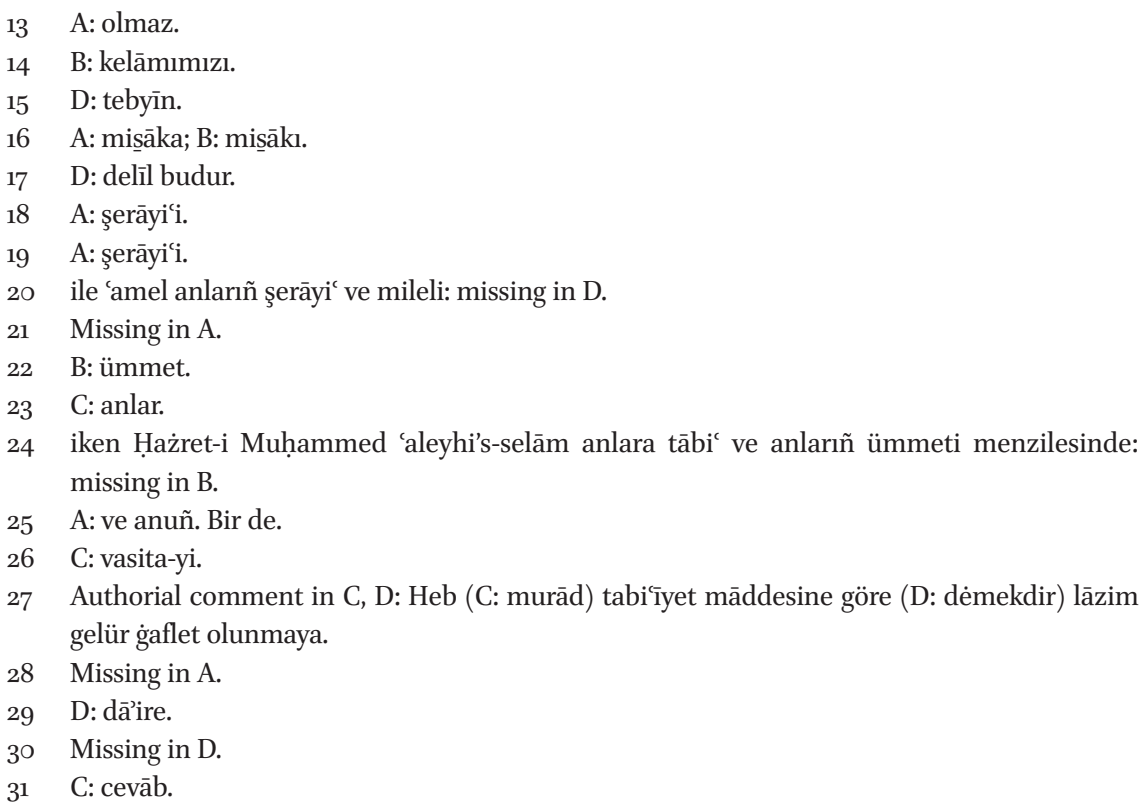


İbrāhīm'denim dẻmeniñ zāhiri buña delālet èder ki millet ḥālā Ḥażret-i İbrāhīm'in olub millet ile 'amel Ḥażret-i İbrāhīm'in ${ }^{32}$ olmak üzerine ola. ${ }^{33}$ Bunda $^{34}$ ise vāḳı'a muhālif oldug̉ından [B 4a] māeadā niçe maḥzūur ${ }^{35}$ vardır ${ }^{36}$ nitekim bir miḳdārin ${ }^{37}$ taḳrīr olundı. Ve șāḥı-i Keșf ve șāhib-i ${ }^{38}$ Takriòr bu şerī‘at hālā Ḥażret-i İbrāhīm milleti olmaḳ mümteni` oldı dẻyu tașrīḥ dahi eylemişlerdir. ${ }^{39}$ Nitekim dẻmişlerdir ki egerçe kim ملة اببكم ابراهيما âyeti ve

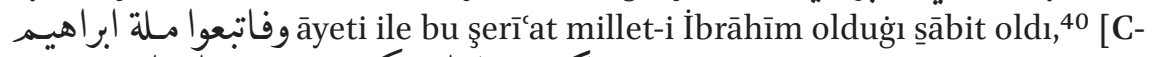

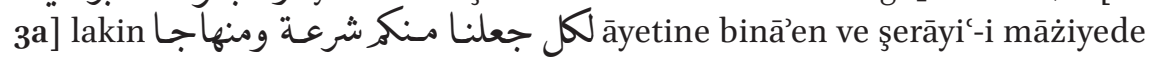

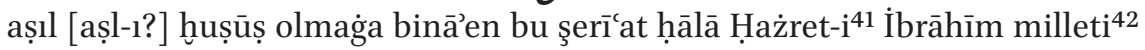
olmak mumteni' oldı.

Öyle olıcak [B 4b] İbrāhīm ${ }^{43}$ milleti44 olmak ne ma'nāyedir? Ol ma'nāyedir $^{45}$ ki [C 3 b] ibtidā’ Ḥażret-i İbrāhīm'iñ idi, ${ }^{46}$ ḥaḳk oldığı ḥālde bāḳi ḳālub ${ }^{47}$ bizim nebīmiziñ ${ }^{48}$ oldı, Ḥażret-i ${ }^{49}$ İbrāhīm'e iżāfetden ḳaldı, māl-ı mevrūs gibi ki ${ }^{50}$ ḥālā vārișe mużāf olub [A 167b] [D 10oa] mūrise ${ }^{51}$ mużāf olmaz dèmişler. ${ }^{52}$

32 olub millet ile 'amel Hażret-i İbrāhīm'iñ: missing in A.

33 A: oluna.

34 D: Bundan.

35 B: maḥuzūrlar; D: maḥūūra.

36 A: vardır ki.

37 AD: miḳdār.

38 ve șāhib-i: missing in D.

39 A: taṣrīh etmişlerdir.

40 Authorial comment in C: [ise] bizim şerīatimiz Hażret-i [C $\mathbf{3}$ b] İbrāhīm milleti olmak ekșer

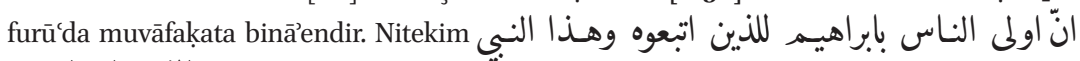

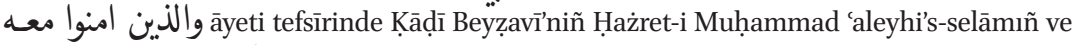
mu’minīniñ Hażret-i İbrāhīm ‘aleyhi’s-selāma ḳarīni ‘alā țarīḳi'l-aṣāla Hażret-i Nebī ‘aleyhi'sselām ve mu’minīn içün meşrū‘a olan aḥkāmiñ ekșerinde Hażret-i İbrāhīm ‘aleyhi's-selāma muvāfakat țarīkiyle ḳurba ḥaml eylemesi delālat èder. Uṣūl-i dīniñ cümlesinde muvāfaḳat ise beyāna muḥtāc degildir, zīrā cemīi enbiyānıñ mileli usūl-i dīne göre muhālife degildir, nitekim işāret olunur.

41 Missing in A.

42 Missing in B.

43 Missing in BD; A has here: 'aleyhi's-selām.

44 C has here an undecipherable word: زسنحس

45 Ol ma'nāyedir: missing in A.

46 A: idügi.

47 D: olub.

48 A: peygamberimiziñ.

49 Missing in D.

$5^{\circ}$ Missing in C.

51 B: mevrūs̄a.

$5^{2}$ BD: dèmişlerdir. 
Bu takrīrātdan ma lūm oldıki Hażret-i İbrāhīm milletindenim dènilmez. ${ }^{53}$ Eger millet 'akā’ide müte'alliḳ ${ }^{54}$ olan eşyāya mahșūṣadır, ${ }^{55}$ öyle olıcak millet-i İbrāhīm'denim dèmek cā’izdir, enbiyā 'aleyhimü's-selām 'aḳāide müte'allik ${ }^{56}$ olan eşyāda muhtalif olmadıḳlarına bināen [B 5 a] dènilürse, dènilür ki tạ̣ḳik budur ki mahșūușa ${ }^{57}$ degildir belki furū'a şāmiledir, vechi ${ }^{58}$ 'ala't-tafșil $1{ }^{59}$ [C 4a] risālemizde beyān olunmışdır. Ve Birgili Mehmed ${ }^{60}$ Efendi merḥūmuñ ${ }^{61}$ dīn ve $^{62}$ millet Ḥażret-i Muḥammed 'aleyhi's-selām'iñ Haḳk teālā'dan i'tiḳāda mütéallik getürdügi şeylerdir dèdigüniñ așlı dahi beyān ${ }^{63}$ olunmışdır. [C 4 b] Faraẓan mahșūṣa olsa bile yine ${ }^{64}$ millet hāāā Ḥażret-i ${ }^{65}$ Muhammed ${ }^{66}$ 'aleyhi's-selāmiñdir, yohssa Ḥażret-i İbrāhīm 'aleyhi's-selām'ıñ ${ }^{67}$ degildir. Ve ol millete ittibā' ve anuñla 'amel Ḥażret-i Muḥammed'ıñ ${ }^{68}$ milleti olmak üzredir, yohssa Ḥażret-i İbrāhīm'iñ milleti olmak üzre degildir. [B 5b] Zīrā yuḳarudaki delīller ve maḥūūrlar uṣūl-i dīn ve furū'a ${ }^{69}$ 'umūm șüretine mahșūṣ degildir, ${ }^{70}$ ușūl-i dīne huṣūṣ șüretinde cārīlerdir. Böyle olıcak millet-i İbrāhīm'denim

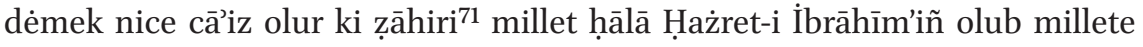
ittibāc ve anuñla 'amel Ḥażret-i İbrāhīm milleti olmaḳ üzerine olmag̉a delālet èder.

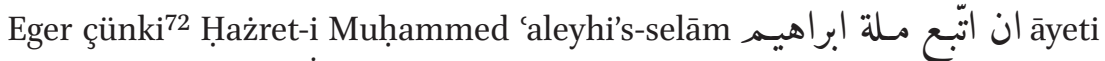
muḳtazāsınca Ḥażret-i İbrāhīm 'aleyhi's-selām milletine ittibā' ile emr olundı ve فاتِّوا مـلة ابراهيـàyeti [C 5a] muḳtaẓāsinca muhāțabūn Ḥażret-i İbrāhīm ${ }^{73}$ milletine ittibā‘ ile emr olundılar, "Millet-i İbrāhīm'denüz" dèmek cầiz olmak

53 AB: dènilemez.

54 B: mütéalliḳa.

55 A: mahșūṣ olursa; C: mahșūṣa derse; D: mahșūuṣdur; F 4478: mahșūusa ise.

56 B: mütéalliḳa.

57 A: mahșūṣ.

58 D: ve cemīc

59 Authorial comment in C.

6o Missing in $\mathrm{AB}$.

61 A: rahime'llāhu 'aleyh.

62 Missing in D.

63 B: zikr.

64 D: gine.

65 Missing in AB.

66 D: İbrāhīm (crossed out).

67 A: Yohssa İbrāhīm'iñ.

68 C: Muhammed 'aleyhi'ṣ-ṣalāt ve'l-selām'iñ.

69 B: usūl ve dīn-i furū'a.

70 A: degildir ve; B: degillerdir; C: degillerdir degillerdir.

71 D: ẓāhir.

72 A: Egerçe kim.

73 C adds: 'aleyhi's-selām. 
görinür dẻnilürse cevāb budur ki yukarırıda żikr olunan delīllere ve maḥzūurlara bināen dèmek cā’iz degildir. [D 1oob] Āyeteynde ${ }^{74}$ ise millet-i İbrāhīm'e ittibāc ile emrden murād aṣlında [A 168a] millet-i İbrāhīm olan millet-i ${ }^{75}$ İslām'a ittibāc ile emrdir. Nitekim șāḥib-i Keșf ve șāhib-i Takrīr kelāmından ${ }^{76}$ böylece müstefāddır ve77 فاتِّعوا مـلة ابراهيم āyetinde Kâại Beyżāvī ve Ebü's-su'ūd Efendi böylece tefsīr eylemişlerdir. Ve Ḥażret-i Muhammed 'aleyhi's-selām șabāḥa dāḩil olduḳda

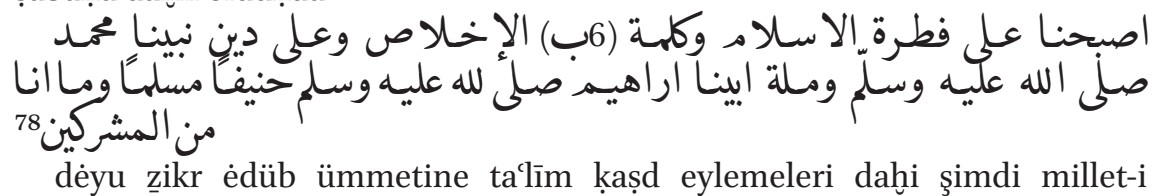
Muhammed [C 5b] olub millet-i İbrāhīm olmayub ancak aṣlında millet-i İbrāhīm olub ${ }^{79}$ millete ittibāc ve anuñ ile 'amel Ḥażret-i Muḥammed milleti olmak üzerine olub ${ }^{80}$ Ḥażret-i İbrāhīm milleti olmamak üzerine olmak ${ }^{81}$ mülāḥaz̧asıyladır. Ve risālemizde dahi niçe țuruḳ beyān olunmuşdur. Eger bu mülāḥaẓa i'tibāriyle millet-i İbrāhīm'deniz dèmek cā’izdir ${ }^{82}$ dènilürse dẻnilür ki 'avām ${ }^{83}$ ẓāhirbīndir ${ }^{84}$ bu mülāḥaẓayı bilmezler, ẓāhirine göre ise [B 7a] cāiz olmadug̉ı muḳarrer oldı.

İmdi 'avām bunı dèmek cāiz degildir, ammā havāạs ${ }^{85}$ zāhirbīn degillerdir, ${ }^{86}$ bu mülāḥaẓayı bilürler, anlara bu mülāḥaẓa ile dèmek ${ }^{87}$ cẩizdir, lākin $^{88}$ dẻyen kimesne zāhirinden müstefād olanı i'tiḳād țarīkiyle dèmiyüb bu mülāhazayı ítikād $^{89}$ țarīkiyle dèdigine ${ }^{90}$ karīne gerekdir ki $^{91}$ istimāc èdenler ol țarīk ile dèmiyüb bu țarīḳ ile dèdigini bileler, zirā ẓāhiri üzerine cầiz degildir.

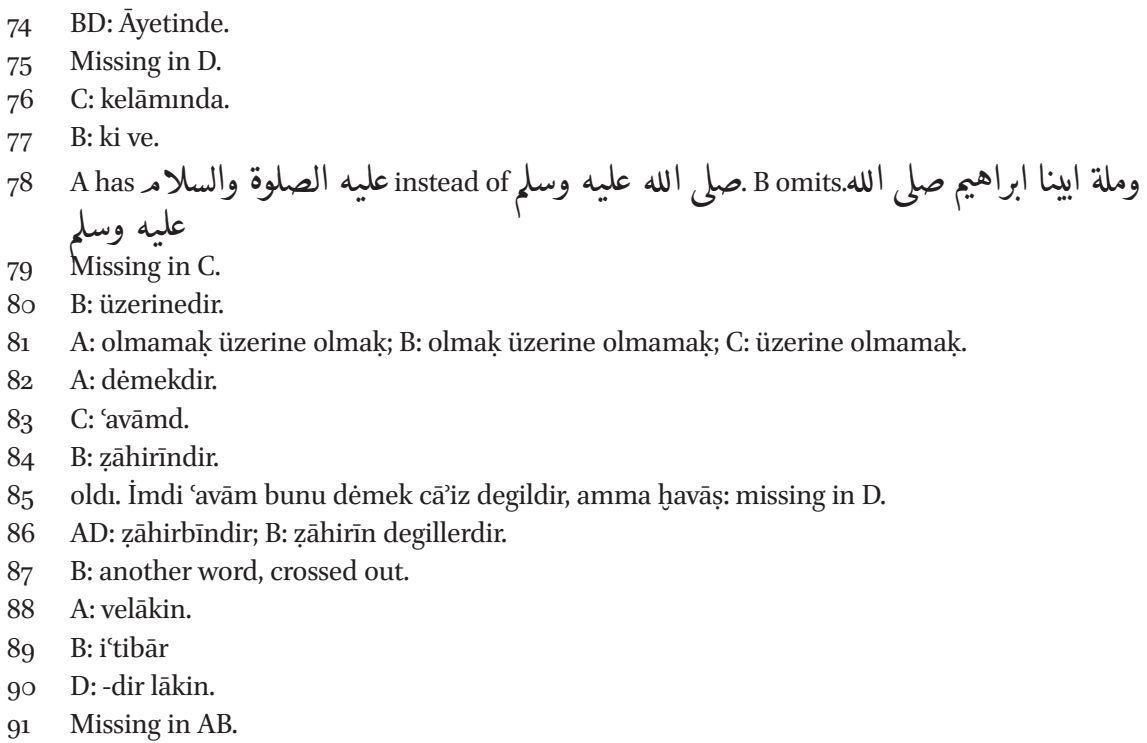


[C 6a] Ve $\mathrm{Ve}^{92}$ bunı bu üslūb üzerine ḩavāṣ yine ḩavāṣ yanında söyleyüb 'avām yanında söylememek gerekdir, zīrā eşitmek ile ${ }^{93}$ zāhirinden [B 7b] müstefād olanı i'tiḳād țarīḳi ile dèye giderler, ${ }^{94}$ ḳarīne ise herkese göre ${ }^{95}$ fā’ide vèrmez ki andan [D 101a] ne i'tiḳad ile dènilür ve ${ }^{96}$ ne i'tikāa ile ${ }^{97}$ dènilmemegi ${ }^{98}$ bileler. [A 168b] Hāṣıllı kelām her söz ẓāhirine maḥmūldır.

İmdi şol söz ki anuñ zāhirinden ${ }^{99}$ müstefād olanı i'tikāa bize cāiz olmaya, ol ${ }^{100}$ sözi söylemek bize ${ }^{101}$ cāiz degildir, i'tikāā cāiiz ${ }^{102}$ olur bir hāle ḳomāduḳca. Bu ḳaldı ki Ḥażret-i Muhammad ${ }^{103}$ 'aleyhi's-selāmıñ ${ }^{104}$ eyledügi șabāh żikrini105 ne keyfiyyet ile eylemek gerekdir, ya ${ }^{106}$ icmālen Hażret ${ }^{107}$ 'aleyhi's-selām ne vech ile ḳaṣd ètdi ise ben dahi ol [B 8a] vechle ḳaṣd èderim dèmek gerekdir, zāhirinden müstefād olanı ${ }^{108}$ ḳaṣd etmemek ${ }^{109}$ gerekdir, yahūd hāāā millet-i Muhammed olub aṣlında millet-i İbrāhīm olan millet üzerine șabāḥa dāḩil oldum [C 6b] dèyu kașd ${ }^{110}$ gerekdir. Va'llāhu ${ }^{111}$ te`ālā a lem, bu miḳdār mug̉nīdir, ${ }^{112}$ tafṣill-i müşbi ${ }^{\text {c113 }}$ murād èden risāle-i muțavvelimize mürāca'at eylesün. ${ }^{114}$

\section{Translation}

In the name of God, the Compassionate, the Merciful. Praise be to God [and] to the Religion of Islam, the Religion of Muhammad. To proceed: In order to

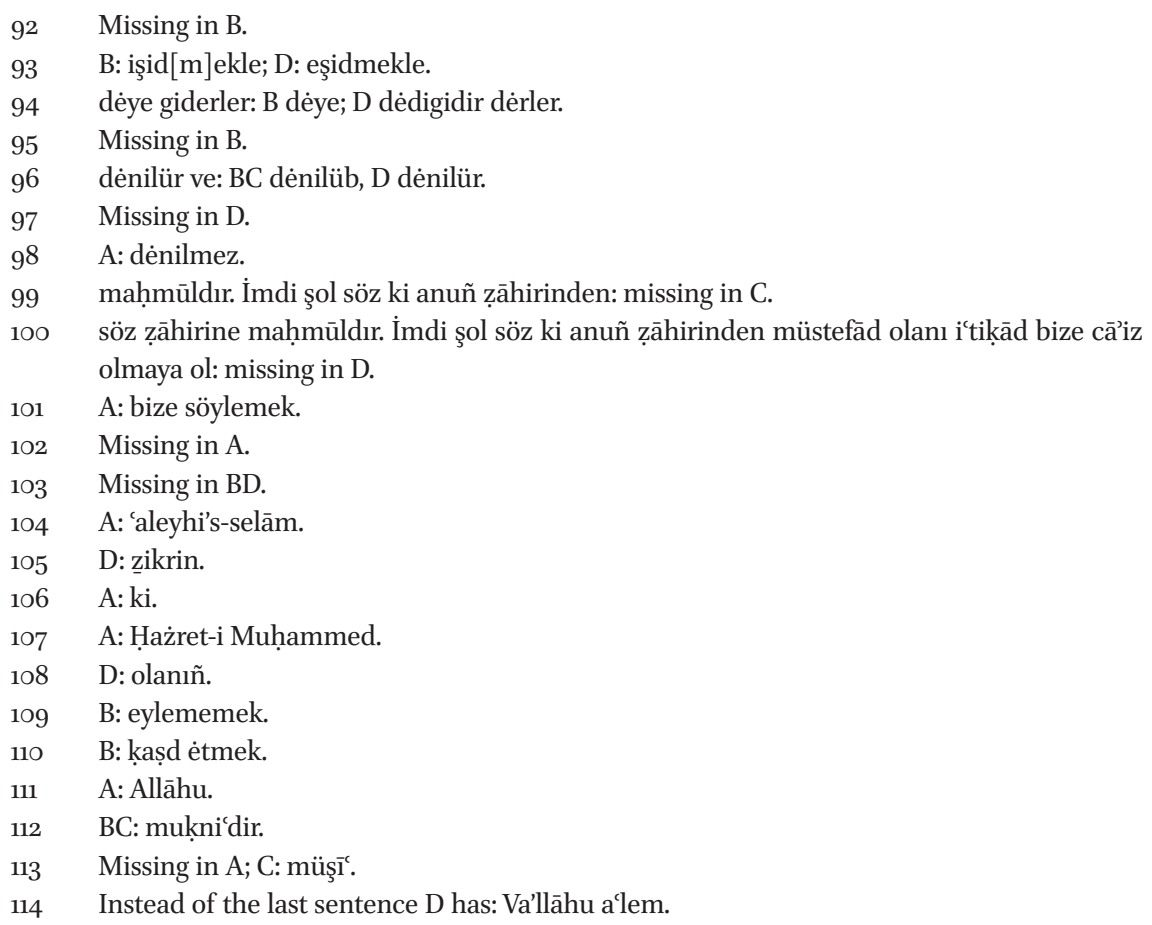


respond to the questions current among the people concerning the Religion of Abraham (millat Ibrāhìm), this humble servant, Minḳāīizāde, wrote about several items that are rarely discussed ('azïzü'l-menäl nīçe vech) and composed an eloquent treatise on the subject. However, since [the treatise] has many ancillary arguments (şi $\left.i^{i} a\right)$, it was summarized and shortened as necessary so that reading it would not be too tiring.

It should be clear to those with insight and understanding that the chosen doctrine established by books of creed (ușül) is that to practice ('amel) an earlier prophet's law and religion means to practice according to our Prophet's law and religion; it does not mean to practice according to that earlier prophet's law and religion. Therefore, the earlier prophet's law and religion have been transferred to our Prophet through inheritance (irs ), as demonstrated in the noble verse, "We gave the Scripture as inheritance to Our chosen servants" (Q35:32).

Let us analyze the meaning of "inheritance" since this is [a case] of transfer by inheritance. When a legacy is transferred from the legator to the legatee it belongs to the legatee and becomes his property; it no longer belongs to the legator and is not his property. In sum, just as a legacy after transmission belongs solely to the legatee and no longer has a connection to the legator, so law and religion (şeríat ve millet) were transferred from the earlier prophets to our Prophet.

These words of ours are taken from the Keş $f$ of Pezdevī, ${ }^{115}$ from the Takrīr, ${ }^{116}$ and from the Tavdīh. ${ }^{117}$ The Kesf $f$ and the Takrïr mention that God almighty said, "God took a pledge from the prophets, saying, "If, after I have bestowed Scripture and wisdom upon you, a messenger comes confirming what you have been given, you must believe in him and support him" (Q3:81). ${ }^{118}$ According to this noble verse, the pledge he took from the prophets is proof that they would follow the Prophet Muhammad and have a place in the Prophet Muhammad's community.

Given the [arguments] above, if practicing ('amel) the earlier prophets' laws and religions meant following their laws and religions, then, just as these [earlier prophets] are followers of the Prophet Muhammad and part of his community, the Prophet Muhammad would be [these prophets'] follower and

115 This is Kashfu'l-asrār by 'Abdulazīz al-Bukhārī (d. 1330), a commentary on the Hanafi ușūl al-fiqh book by Fakhru'l-Islām al-Pazdawī.

116 Akmal al-Dīn al-Bābartīs (d. 1384) commentary on al-Pazdawī, called al-Taqrīr fi sharh al-ușūl al-Pazdawì.

117 This text is likely the al-Tawdīh fi hall ghawämid al-tankịh by Ṣadr al-Sharīa 'Ubayd Allah b. Mas'ūd (d. 1346).

118 Translation of Q3:81 taken from M.A.S. Abdel Haleem, trans., The Qur'an (Oxford: Oxford University Press, 2004), 40. 
part of their community. According to Imam Nesefi in his commentary on the Menār, if to practice [religion] meant following an earlier prophet's law and religion, then the Prophet Muhammad wouldn't be God's messenger, but an earlier prophet's messenger, and [the Prophet Muhammad] would have to be an intermediary between him and his community. ${ }^{119}$

Now, as for the current question, they ask whether or not it is permissible for someone from Muhammad's community to say, "I belong to the religion of Abraham." As demonstrated [above], it is clear that the answer is that it is not permissible. Because the literal meaning of the statement "I belong to the religion of Abraham" indicates that the religion (millet) [i.e. Islam] still belongs to the Prophet Abraham and that the practice of the religion should occur according to that of the Prophet Abraham. If this were true, besides being contrary to the fact of the matter, there would be many other objections, a number of which have already been demonstrated. The author of the Kesf and the author of the Takrï have also explained that it is impossible for our law ( $b u$ şeriat) to still be the Prophet Abraham's religion. Indeed, they say that although the verses "the religion of your father, Abraham" (Q22:78) and "Follow the religion of Abraham" (Q3:95) establish that our law is the religion of Abraham, ${ }^{120}$ nevertheless, based on the verse "We have assigned a law and a path to each of you" (Q5:48) and based on the fact that [these verses] apply only for laws of the past, it is impossible that our law is still the Prophet Abraham's religion.

If this is the case, then what does it mean to belong to Abraham's religion? It means that initially it [the millet/religion] was that of Prophet Abraham and it remained so as long as it stayed true. Then [the religion] became that of our Prophet and it no longer belonged to the Prophet Abraham. It is like they say of a bequest, that it now belongs to the legatee and no longer belongs to the legator.

From what has been demonstrated above, it is clear that one cannot say, "I belong to the religion of Abraham." If it is claimed that religion (millet) is

119 Authorial comment in C, D: Don't overlook the fact that this would be necessary according to the meaning of the term "following" [an earlier prophet's law and religion].

120 Authorial comment in C: The fact that our law (şeriat) is that of the Prophet Abraham's religion (millet) is based upon the agreement of most [of the sources] on religious practice. Thus, in his commentary on the verse, "And the people who are closest to Abraham are those who truly follow his ways, this Prophet, and [true] believers" (Q3:68), Kāḍi Beyżavī affirms that the Prophet Muhammad and his believers are closely connected by lineage to the Prophet Abraham and his believers and attributes this close connection to the agreement of most of the Prophet Muhammad's legal rulings with those of the Prophet Abraham. As for the agreement regarding the principles of religion, it is not necessary to explain this because none of the prophets' religions contradict one another according to the principles of religion. 
limited to matters of creed, given that the prophets do not disagree on matters of creed, and it is therefore permissible to say "I belong to the religion of Abraham," then the response is that the reality is that it [i.e. millet] is not limited [to matters of creed] but also applies to law (furū). This point is explained in detail in our treatise, which also expounds on the late Birgili Mehmed Efendi's statement that din and millet are things that the Prophet Muhammad brought from God Almighty concerning creed. Even if it [i.e. millet] were limited [to matters of creed], the religion now is that of the Prophet Muhammad, it is not that of the Prophet Abraham; and following and practicing that religion means belonging to the Prophet Muhammad's religion, it does not mean belonging to the Prophet Abraham's religion. The reason is that the above proofs and objections are not limited to the principles of religion (ușül-i dìn) and to law (furü') generally ('umūm șüretine); rather they cover the principles of religion specifically (husuus șüretine). ${ }^{121}$ This being so, how can it be permissible to say "I belong to the religion of Abraham?" Taken literally, [this statement] attests that the religion (millet) [i.e. Islam] is still the Prophet Abraham's and that it should be followed and practiced according to [the precepts] of the Prophet Abraham's religion.

If it is claimed that it seems permissible to say "We belong to the religion of Abraham," because both the Prophet Muhammad in the verse "Follow the religion of Abraham" (Q16:123) and those addressed in the verse "So follow the religion of Abraham" (Q3:95) were commanded to follow the religion of the Prophet Abraham, we respond that based on the aforementioned proofs and objections it is not permissible. As for these two verses, what is actually meant by the command to follow the religion of Abraham is to follow the religion of Islam, which is the religion of Abraham, The authors of the Kes $f$ and the Takrir understood it like this and Kâḍi Beyżavī and Ebü's-su'ūd Efendi also interpreted the verse "So follow the religion of Abraham" in this way.

When the Prophet Muhammed would awake in the morning he would say, "We awake into the state of Islam, the word of pure faith, and into the religion of our Prophet Muhammad and the religion of our forefather Abraham, who was of true faith and a Muslim and was not one of the polytheists."122 He said this [supplication] with the intention of teaching the community that now it [i.e. the religion/Islam] is Muhammad's religion and not Abraham's religion. Although we must consider that it originally was the religion of

\footnotetext{
121 In this sentence, "general" and "specific" appear to be terms taken from logic.

122 I have translated the hadith according its main renditions, which have the last clause as "ما كان من المشركن" instead of the alternative rendition, "ما أنا من المشركين," found in Minḳārīzāde's text.
} 
Abraham, practicing and following it [now] means belonging to the Prophet Muhammad's religion, not the Prophet Abraham's religion. Various aspects of this are discussed in our [longer] treatise. If it is claimed that it is permissible to say "We belong to the religion of Abraham," based on the above consideration (mülāhaza), the response is that ordinary people ('avām) are literalists, that they do not understand this consideration, and that [the statement] has been ruled impermissible according to its literal meaning.

Now, it is not permissible for ordinary people to say this [statement, "we belong to the religion of Abraham"]. The educated elite (havass), however, are not literalists; they understand the above consideration and, keeping it in mind, they are allowed to say it. But when they do so they must never say it with any belief in its literal meaning. Rather they must add the proviso (karine) that they say it with belief in this consideration, so that those who hear it know that it is not said in that way [i.e., in its literal meaning] but in this way [i.e., with the proviso], as it is not permissible [to say it] according to its literal meaning. Still, the educated elite should say [the statement] only in the presence of other educated elites and not in the presence of ordinary people, because, when they hear it, they will think that it is spoken with belief in its literal meaning. That said, the proviso can't help everyone know whether or not the statement was said with belief. In sum, every statement is understood according to its literal meaning.

Now, it is not permissible for us to say any word whose literal meaning we are not allowed to believe, unless it is phrased in such a way that it is permissible to believe. It remains to be determined the situation regarding the Prophet Muhammad's morning supplication. Either one must say in general that one intends the statement in whatever way or manner the Prophet Muhammad intended it, but one must not intend its literal meaning; or one must intend by it: "I awake into the religion that was the religion of Abraham and is now the religion of Muhammad." God knows best and this must suffice. Those who wish additional evidence and details may consult my extended treatise. 